\title{
Effects of Rain Gardens on the Quality of Water in the Minneapolis-St. Paul Metropolitan Area of Minnesota, 2002-04
}

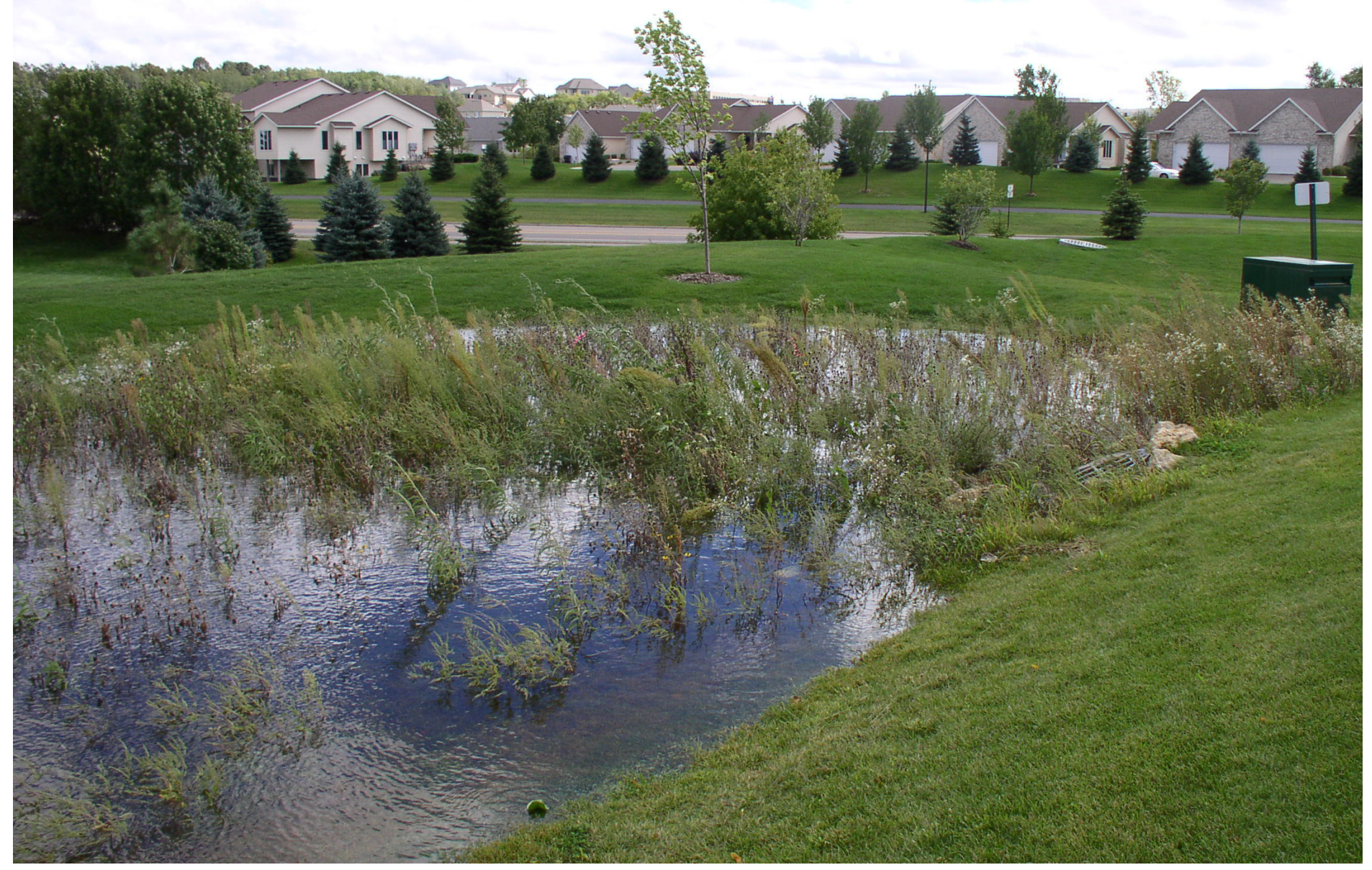

Scientific Investigations Report 2005-5189

Prepared in cooperation with the Metropolitan Council of the Twin Cities

U.S. Department of the Interior

U.S. Geological Survey 
Cover: Photograph showing rain-garden site at Lakeville, Minnesota, September 2004. (All photographs in this report were taken by U.S. Geological Survey employees.) 


\title{
Effects of Rain Gardens on the Quality of Water in the Minneapolis-St. Paul Metropolitan Area of Minnesota, 2002-04
}

\author{
By Lan H. Tornes
}

Scientific Investigations Report 2005-5189

Prepared in cooperation with the Metropolitan Council of the Twin Cities

U.S. Department of the Interior

U.S. Geological Survey 


\section{U.S. Department of the Interior \\ Gale A. Norton, Secretary}

\section{U.S. Geological Survey P. Patrick Leahy, Acting Director}

Use of trade, product, or firm names in this report is for identification purposes only and does not constitute endorsement by the U.S. Geological Survey.

Mounds View, Minnesota, 2005

For additional information write to:

U.S. Geological Survey

Director, USGS Water Science Center of Minnesota

2280 Woodale Drive

Mounds View, MN 55112

http://mn.water.usgs.gov/

For more information about the USGS and its products:

Telephone: 1-888-ASK-USGS

World Wide Web: http://www.usgs.gov/

Although this report is in the public domain, permission must be secured from the individual copyright owners to reproduce any copyrighted materials contained within this report.

Scientific Investigations Report 2005-5189 


\section{Contents}

Abstract
Introduction
Purpose and Scope
Acknowledgments
Description of Study Sites
Methods
Water Quality at Rain-Garden Sites
Chanhassen
Hugo

\section{Figures}

Figure 1. Schematic diagram of expected processes and monitoring points of a rain garden. ................... 2

Figure 2. Location of rain-garden sampling sites and percentage of clay in soils in the Minneapolis-

St. Paul metropolitan area of Minnesota........................................................................................ 4

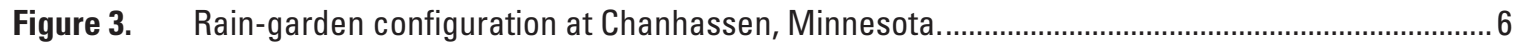

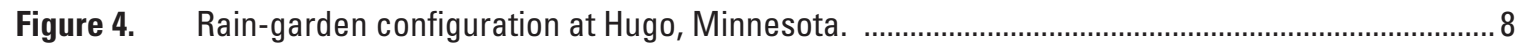

Figure 5. Rain-garden configuration at Lakeville, Minnesota. ................................................................... 9

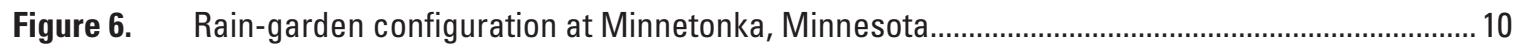

Figure 7. Rain-garden configuration at Woodbury, Minnesota. .................................................................. 11

Figure 8. Distribution of specific conductance and phosphorus, chloride, and suspended-solids concentration at each of the five rain-garden sites sampled in the Minneapolis-St. Paul metropolitan area of Minnesota, 2004-04

Figure 9. Distribution of specific conductance of water samples collected from inflow and raingarden lysimeter and well at each of the five sites sampled in the Minneapolis-St. Paul metropolitan area of Minnesota, 2002-04

Figure 10. Change in chloride, nitrite plus nitrate nitrogen filtered, and total phosphorus concentration at the Hugo and Woodbury rain-garden sites in the Minneapolis-St. Paul metropolitan area of Minnesota, 2002-04... 


\section{Tables}

Table 1. Rain-garden sites sampled in the Minneapolis - St. Paul metropolitan area of Minnesota...........5

Table 2. Lithologic log of wells installed at rain-garden sites in the Minneapolis - St. Paul metropolitan area of Minnesota ...

Table 3. Median values of selected physical properties, chemical constituents, and nutrient species of water from the rain-garden site in Chanhassen, Minnesota, 2002-04.

Table 4. Median values of selected physical properties, chemical constituents, and nutrient species of water from the rain-garden site in Hugo, Minnesota, 2002-04.

Table 5. Median values of selected physical properties, chemical constituents, and nutrient species of water from the rain-garden site in Lakeville, Minnesota, 2002-04

Table 6. Median values of selected physical properties, chemical constituents, and nutrient species of water from the rain-garden site in Minnetonka, Minnesota, 2002-04.

Table 7. Median values of selected physical properties, chemical constituents, and nutrient species of water from the rain-garden site in Woodbury, Minnesota, 2002-04

Table 8. Median specific-conductance value and chloride concentration at each of the five rain-garden sites in the Minneapolis-St. Paul metropolitan area of Minnesota, 2004

\section{Conversion Factors, Datums, and Abbreviated Water-Quality Units}

\begin{tabular}{ccc}
\hline Multiply & By & To obtain \\
\hline inch (in.) & 2.54 & centimeter $(\mathrm{cm})$ \\
foot $(\mathrm{ft})$ & 0.3048 & meter $(\mathrm{m})$ \\
mile $(\mathrm{mi})$ & 1.609 & kilometer $(\mathrm{km})$ \\
square mile $\left(\mathrm{mi}^{2}\right)$ & 2.590 & square kilometer $\left(\mathrm{km}^{2}\right)$ \\
\hline
\end{tabular}

Water temperature is reported in degrees Celsius $\left({ }^{\circ} \mathrm{C}\right)$, which can be converted to degrees Fahrenheit $\left({ }^{\circ} \mathrm{F}\right)$ by using the following equation:

$$
{ }^{\circ} \mathrm{F}=\left(1.8 x^{\circ} \mathrm{C}\right)+32 \text {. }
$$

Vertical coordinate information is referenced to the North American Vertical Datum of 1988 (NAVD 88). Horizontal coordinate information is referenced to the North American Datum of 1927 (NAD 27).

Chemical concentration is reported only in metric units. Chemical concentration is reported in milligrams per liter (mg/L), which is a unit expressing the mass of solute (milligrams) per unit volume (liter) of water. For concentrations less than 7,000 milligrams per liter, the numerical value is about the same as for concentrations in parts per million. Specific conductance is reported in microsiemens per centimeter at 25 degrees Celsius $(\mu \mathrm{S} / \mathrm{cm})$. 


\section{Effects of Rain Gardens on the Quality of Water in the Minneapolis-St. Paul Metropolitan Area of Minnesota, 2002-04}

\author{
By Lan H. Tornes
}

\section{ABSTRACT}

Rain gardens are a popular method of managing runoff while attempting to provide aesthetic and environmental benefits. Five rain-garden sites in the Minneapolis - Saint Paul metropolitan area of Minnesota were instrumented to evaluate the effects of this water-management system on surface and subsurface water quality. Most of these sites were in suburban locations and frequently in newer developments. Because of this they were affected by changing hydrology during the course of this study.

Less-than-normal precipitation during much of the study may have resulted in samples that may not be representative of normal conditions. However, the resulting data indicate that properly designed rain gardens enhance infiltration and can reduce concentrations of dissolved ions relative to background conditions.

The runoff events in one rain garden and several runoff events in the other rain gardens produced no sampled overflow during this study because the gardens captured all of the inflow, which subsequently infiltrated beneath the land surface, evaporated, or transpired through garden vegetation. Where measured, overflow had reduced concentrations of suspended solids and most nutrient species associated with particulate material, as compared to inflow. Many of these materials settle to the bottom of the rain garden, and some nutrients may be assimilated by the plant community.

Site design, including capacity relative to drainage area and soil permeability, is an important consideration in the efficiency of rain-garden operation. Vegetation type likely affects the infiltration capacity, nutrient uptake, and evapotranspiration of a rain garden and probably the resulting water quality. The long-term efficiency of rain gardens is difficult to determine from the results of this study because most are still evolving and maturing in relation to their hydrologic, biologic, and chemical setting. Many resource managers have questioned what long-term maintenance will be needed to keep rain gardens operating effectively. Additional or continued studies could address many of these concerns.

\section{INTRODUCTION}

Several means have been used to deal with storm-water runoff in urban areas. Traditional systems of curbs, gutters, and storm drains carry storm-water runoff directly to local streams and rivers without any bioretention, filtering, processing, or attenuation of runoff. This direct runoff can result in erosion and delivery of sediment and nutrients to receiving waters. Catch basins allow sediment to settle and retain nutrients that reduce the amount of material transported to nearby streams and lakes. Although effective at attenuating runoff and suspended solids, they often create a hazard and can create breeding grounds for mosquitoes and other pests.

Rain gardens are becoming important landscape tools for water managers and land-use planners. These retention basins provide water storage and an area for infiltration of stormwater runoff while providing attractive landscaping. Rain gardens are designed to retain runoff and encourage infiltration to ground water. Retention encourages uptake and biodegradation of compounds that may be present in the runoff. The assumption of rain-garden design is that sediment, nutrient, and other chemical removal occurs as the runoff comes in contact with the soil, bacteria, and roots of shrubs or other vegetation within the rain garden. It also is assumed that this process results in improved surface-water overflow quality, and improved quality and amount of ground water as a result of infiltration.

Rain gardens are being installed around the United States (Rain Garden Network, 2005), including in several communities around the Minneapolis-St. Paul metropolitan area of Minnesota. Although data have been collected from some sites, few published studies document effects of the rain gardens on the quality of surface and ground water. To help address this need for information, a study was done by the U.S. Geological Survey (USGS) in cooperation with the Metropolitan Council of the Twin Cities, Department of Environmental Services, during 2002-04. The objective of the study was to describe the quality of water as it flowed into and through rain gardens following runoff events.

The expected processes that occur in rain gardens and an idealized schematic diagram of typical site instrumentation are shown in figure 1. Runoff water is directed into the rain 


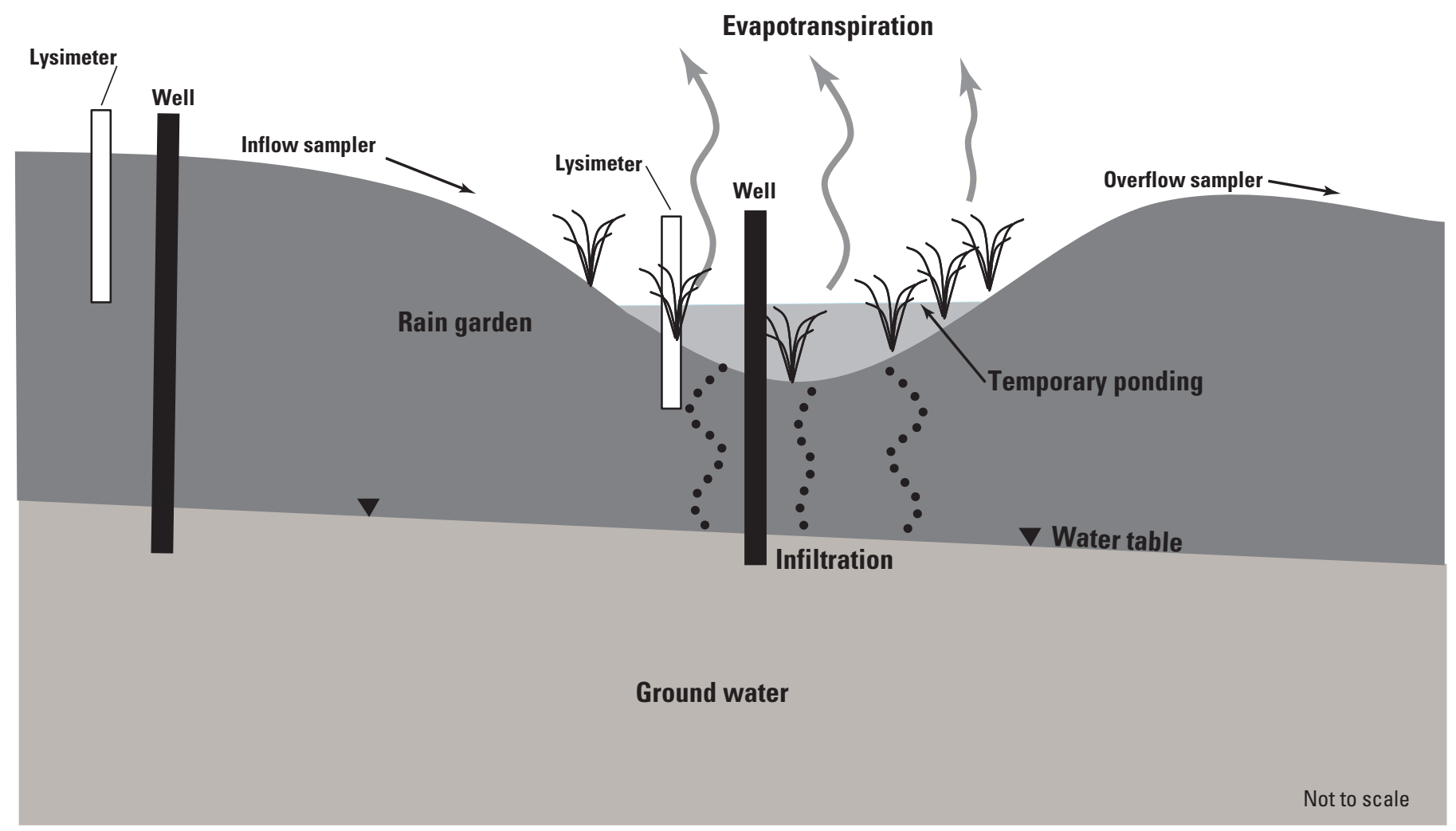

Figure 1. Schematic diagram of expected processes and monitoring points of a rain garden.

garden through storm drainage and subsequently allowed to pond temporarily until water can infiltrate into the ground and (or) be taken up by the garden vegetation. Rain gardens are designed to overflow during large runoff events with a specified recurrence interval. Retained water undergoes a variety of biotic or abiotic processes that include uptake by vegetation with subsequent transpiration, evaporation, and infiltration. Sedimentation and biological transformation also remove suspended solids, nutrients, and other contaminants that could be detrimental to receiving waters.

\section{Purpose and Scope}

This report discusses the results from sampling rain-garden sites located throughout the Minneapolis-St. Paul metropolitan area during June 2002 through October 2004. The amount of precipitation, the volume of inflow and overflow, and the amount of infiltration and other losses were not measured and were not considered in this report. Sources of water to the rain gardens were evaluated only qualitatively because most sites had relatively flat contributing areas that may have sporadically added to the inflow.

Sampling focused primarily on determining the concentration of a few selected constituents considered to be indicative of runoff including suspended solids (particulate material carried in suspension by flowing water, also called residue, total at 105 degrees Celsius, suspended), nitrogen, phospho- rus, chloride, and gross measures of dissolved constituents. Although the changes in mass transported throughout the system relative to sources were not measured, the data provide initial information to evaluate measured concentrations in components of the water system in a rain garden that were sampled and determine how they interrelate at each of the sites sampled. Other important factors including precipitation characteristics, antecedent conditions, and flow volumes from which to compute loads were not measured. Longduration storms that exceeded the capacity of the automatic samplers were not adequately sampled. Other factors that could contribute to a better understanding of the systems including delineation of drainage areas, contributing drainage areas, and detailed information on land-use characteristics also were beyond the scope of this study. Determining how these samples relate to the existing climate or changing climate, changes in land use, and other factors also was beyond the scope of this report.

Results in this report will improve understanding about the fate of chemical constituents transported to rain gardens in runoff and can be used by water managers and land-use planners to better understand the environmental impacts and effectiveness of rain gardens in protecting water quality. This can lead to improved designs and enhanced protection for surface and ground water. Findings about the significance of local site conditions, such as soil texture and permeability, will allow for improved rain-garden design that more effectively 
treats storm-water runoff. Results should be transferable to other areas of the nation.

\section{Acknowledgments}

The USGS gratefully acknowledges the Metropolitan Council of the Twin Cities, Department of Environmental Services, who supported and helped design this study. Gratitude also is extended to all of the local units of government, developers, and landowners who assisted with installation and allowed continued access to these sites. The following companies provided maps of rain-garden design that were used to sketch simplified diagrams of sites shown in figures 3 , 4, 5, and 7, respectively: Bonestroo, Rosene, Anderlick, and Associates; Emmons and Olivier Resources, Inc.; Westwood Professional Resources; and Barr Engineering.

\section{Description of Study Sites}

The Minneapolis-St. Paul metropolitan area of Minnesota is situated on relatively flat to gently rolling land that was mostly prairie before settlement. Relief is much greater near the rivers and streams that cross the area. Most of the area has an altitude of about 1,000 ft or less. The rain-garden sites that were studied range in altitude from about 925 to more than $1,000 \mathrm{ft}$.

Five rain-garden sampling sites were selected with the input from the Metropolitan Council of Environmental Services and other interested stakeholders. The sites represent a wide range of hydrologic and land-use conditions that also represent a range of impervious surface conditions that included parking lots, driveways, walkways, and roofs. The rain gardens also may receive runoff from grassy areas including athletic fields and lawns.

The five sites (fig. 2) are located in the communities of Chanhassen, Hugo, Lakeville, Minnetonka, and Woodbury. The sites are distributed across an area of nearly 4,000 $\mathrm{mi}^{2}$ within the seven-county Minneapolis-St. Paul metropolitan area. The percentage of clay in the uppermost $5 \mathrm{ft}$ of the soil profile (fig. 2) was estimated from the State Soil Geographic (STATSGO) data for Minnesota by averaging the percentage of clay in mapped units of the soil profile. The STATSGO data set is "... a digital general soil association map developed by the National Cooperative Soil Survey. It consists of a broad based inventory of soils areas that occur in a repeatable pattern on the landscape and that can be cartographically shown at the scale mapped. The soil maps for STATSGO are compiled by generalizing more detailed soil survey maps. Where more detailed soil survey maps are not available, data on geology, topography, vegetation, and climate are assembled, together with Land Remote Sensing Satellite (LANDSAT) images. Soils of like areas are studied, and the probable classification and extent of the soils are determined." (U.S. Department of Agriculture, 2005).
The sampling sites at each of the rain gardens sampled for this study are listed in table 1. Also included is information, such as site identifier, that would be useful in locating additional information about these sites and the actual data that are currently (2005) available.

The climate across the area ranges from relatively warmer in the southwest to relatively cooler in the northeast. However, these long-term climate patterns often are confounded by weather systems that have local effects.

Climate conditions in the area are relatively uniform. Normal mean monthly temperatures at the Minneapolis -St. Paul International Airport (1971-2000) vary from $70.6^{\circ} \mathrm{F}$ (August) to $13.1^{\circ} \mathrm{F}$ (January) and average $45.4^{\circ} \mathrm{F}$ annually. These normal means are slightly higher in the south and west and lower in the north and east. Inner-city areas are slightly warmer than outlying areas at all times of the year (Minnesota Department of Natural Resources, 2005a).

Seasonal variability in precipitation also occurs in the area. Nearly two-thirds of normal mean annual precipitation falls during the growing season from May through September and only 8 percent of the normal mean annual precipitation falls in the winter (December through February). Normal annual precipitation varies across the area from about 29 to 30 in. and increases from the southwest to the northeast. The lowest normal mean monthly precipitation occurs in August (Minnesota Department of Natural Resources, 2005b).

During parts of this study, precipitation was less than normally would be expected. This resulted in collection of fewer samples than were anticipated during certain seasons.

Climatic variations are minor among the rain-garden sites. Weather variations resulting from convective thunderstorms are more likely to create variability among sites and result in substantial differences in the amount of precipitation delivered to the rain gardens studied. Use of other hydrologic data, including records of precipitation, inflow and overflow volumes, and rates of evapotranspiration, which could have been useful to estimate loading and attenuation of materials delivered to the rain gardens, was beyond the scope of this study.

The effectiveness of rain gardens is related to the topographic and land-use settings of each site, including the texture and hydraulic conductivity of soils and unconsolidated glacial deposits that underlie the sites. Most of the rain-garden sites were chosen with the intention of capturing runoff immediately downstream from an impervious surface, such as a roof or parking lot, and soil characteristics were not always as important a consideration as location. Although the soil types (fig. 2) are a general guide, local variations may occur that cannot be mapped at the scale shown. Soil tests and other engineering considerations similar to a percolation test take into account the variables that contribute to infiltration in a rain garden. The site at Lakeville apparently had a highly permeable substrate that resulted in little or no overflow from the storms sampled, but another rain garden being installed (2005) about $1 \mathrm{mi}$ north of the existing rain garden does not have the permeable substrate and requires special engineering 


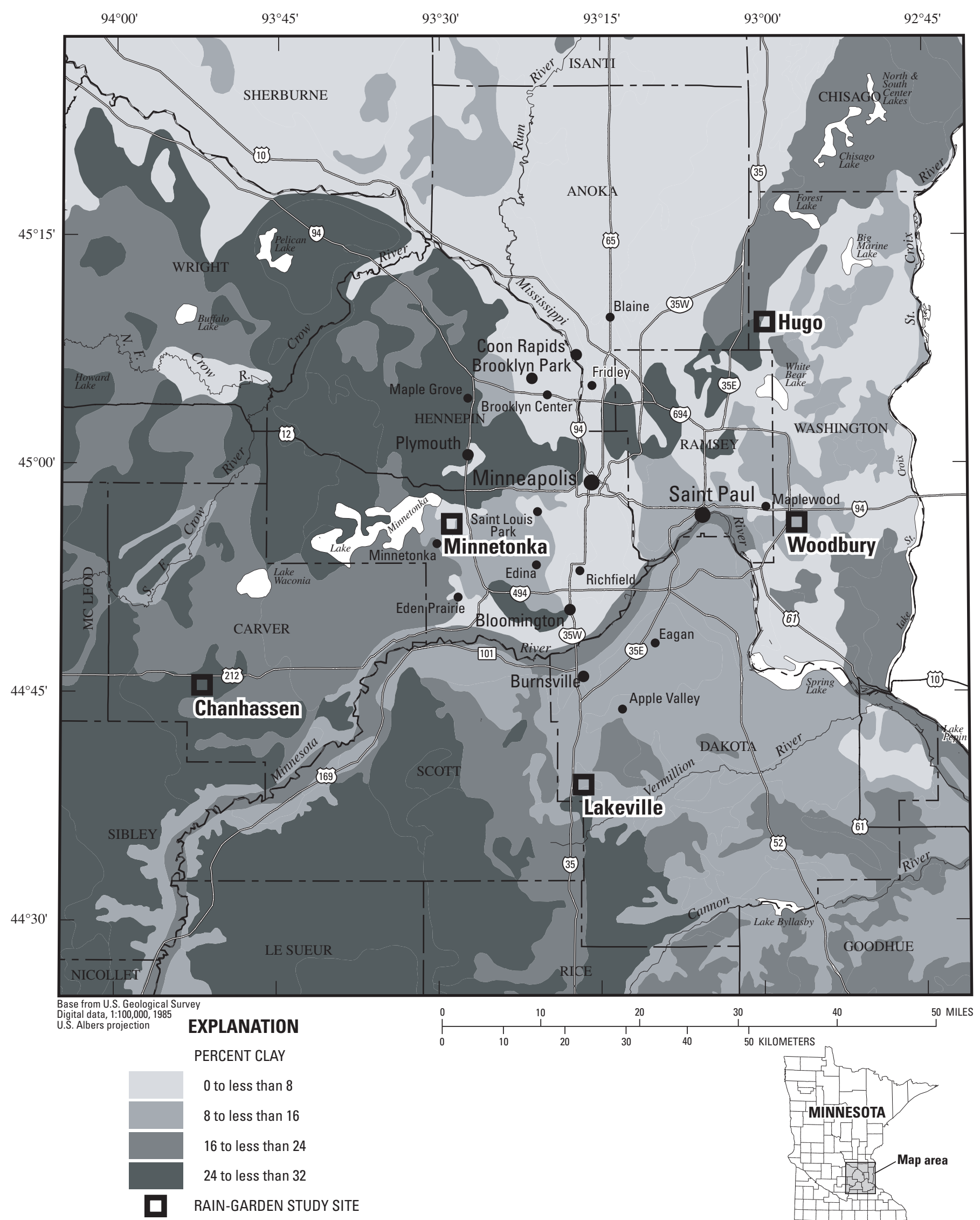

Figure 2. Location of rain-garden sampling sites and percentage of clay in soils in the Minneapolis-St. Paul metropolitan area of Minnesota. 
Table 1. Rain-garden sites sampled in the Minneapolis - St. Paul metropolitan area of Minnesota

[Latitude and longitude: DD, degrees; MM, minutes; SS, seconds; NA, not applicable]

\begin{tabular}{|c|c|c|c|c|c|}
\hline Site identifier & Site name & $\begin{array}{l}\text { Latitude } \\
\text { DDMMSS }\end{array}$ & $\begin{array}{l}\text { Longitude } \\
\text { DDMMSS }\end{array}$ & Start date & End date \\
\hline 445149093365502 & Rain garden lysimeter near Chanhassen, $\mathrm{MN}$ & 445149 & 0933655 & Aug. 2003 & Nov. 2004 \\
\hline 445149093365503 & Rain garden inflow near Chanhassen, $\mathrm{MN}$ & 445149 & 0933655 & Sep. 2003 & Sep. 2004 \\
\hline 445150093365402 & Rain garden background lysimeter near Chanhassen, MN & 445150 & 0933654 & Sep. 2003 & Oct. 2004 \\
\hline 445150093365403 & Rain garden outflow near Chanhassen, MN & 445150 & 0933654 & Aug. 2003 & Sep. 2004 \\
\hline 450943092593901 & Rain garden well at Hugo, MN & 450943 & 0925939 & Aug. 2002 & Nov. 2004 \\
\hline 450943092593902 & Rain garden lysimeter at Hugo, MN & 450943 & 0925939 & Aug. 2002 & Nov. 2004 \\
\hline 450943092593903 & Rain garden inflow at Hugo, $\mathrm{MN}$ & 450943 & 0925939 & Jul. 2002 & Sep. 2004 \\
\hline 450946092593901 & Rain garden background well at Hugo, MN & 450946 & 0925939 & Jun. 2002 & Nov. 2004 \\
\hline 450946092593902 & Rain garden background lysimeter at Hugo, MN & 450946 & 0925939 & Aug. 2002 & Nov. 2004 \\
\hline 450946092593903 & Rain garden outflow at Hugo, MN & 450946 & 0925939 & NA & NA \\
\hline 443914093171801 & Rain garden well at Lakeville, MN & 443914 & 0931718 & Sep. 2002 & Nov. 2004 \\
\hline 443914093171802 & Rain garden lysimeter at Lakeville, $\mathrm{MN}$ & 443914 & 0931718 & Sep. 2002 & Nov. 2004 \\
\hline 443914093171803 & Rain garden inflow at Lakeville, $\mathrm{MN}$ & 443914 & 0931718 & Sep. 2003 & Sep. 2004 \\
\hline 443920093173501 & Rain garden background well at Lakeville, MN & 443920 & 0931735 & Oct. 2002 & Nov. 2004 \\
\hline 443914093173602 & Rain garden background lysimeter at Lakeville, MN & 443914 & 0931736 & Sep. 2002 & Nov. 2004 \\
\hline 443920093173503 & Rain garden outflow at Lakeville, MN & 443920 & 0931735 & NA & NA \\
\hline 445643093253801 & Rain garden well near Minnetonka, MN & 445643 & 0932538 & Nov. 2003 & Oct. 2004 \\
\hline 445643093253802 & Rain garden lysimeter near Minnetonka, MN & 445643 & 0932538 & Aug. 2003 & Oct. 2004 \\
\hline 445643093253803 & Rain garden inflow near Minnetonka, MN & 445643 & 0932538 & Aug. 2003 & Oct. 2004 \\
\hline 445645093254001 & Rain garden background well near Minnetonka, MN & 445645 & 0932540 & Aug. 2003 & Oct. 2004 \\
\hline 445645093254002 & Rain garden background lysimeter near Minnetonka, MN & 445643 & 0932538 & Aug. 2003 & Aug. 2004 \\
\hline 445645093254003 & Rain garden outflow near Minnetonka, MN & 445645 & 0932540 & Aug. 2003 & Oct. 2004 \\
\hline 445512092564401 & Rain garden well near Woodbury, MN & 445512 & 0925644 & Oct. 2002 & Oct. 2004 \\
\hline 445512092564402 & Rain garden lysimeter near Woodbury, MN & 445512 & 0925644 & Aug. 2003 & Oct. 2004 \\
\hline 445512092564403 & Rain garden inflow near Woodbury, MN & 445512 & 0925644 & Jun. 2003 & Sep. 2004 \\
\hline 445516092563801 & Rain garden background well near Woodbury, MN & 445516 & 0925638 & Oct. 2002 & Oct. 2004 \\
\hline 445516092563802 & Rain garden background lysimeter near Woodbury, MN & 445516 & 0925638 & Aug. 2003 & Aug. 2004 \\
\hline 445516092563803 & Rain garden outflow near Woodbury, MN & 445516 & 0925638 & Jun. 2003 & Sep. 2004 \\
\hline
\end{tabular}


to encourage infiltration (Keith Nelson, Lakeville City Engineer, oral commun., 2005). Soils maps indicate that both the established and under-construction rain gardens are situated in the same type of soils. Other considerations such as the watertable altitude also may affect infiltration and may need to be evaluated on a site-specific basis.

The closest resemblance to a soil test available for this study was the lithologic logs for the monitoring wells that were installed at the rain-garden sites (table 2). Materials encountered ranged from coarse sand to clay, with some gravel and cobbles. The least-permeable material was present at Chanhassen, where wells were not installed because the clay was impervious to water transport.

Many of the rain gardens have multiple inflows because water can come from several surrounding impervious surfaces. Rain gardens generally are situated in low-lying areas. Because it is difficult to install multiple intakes that can collect a representative, proportionate sample from each of the inflows, one inflow was selected at each site that was expected to provide the largest, most representative inflow to that rain garden. These largest inflows are assumed to be the appropriate sampling sites for this qualitative study.

The typical site installation (fig. 1) encompassed two automatic samplers. One was configured to collect water at the primary site of inflow. The other was configured to sample the overflow when sufficient water passed into and through the rain garden to generate overflow. A well and lysimeter were installed within the rain garden to measure the quality of water that might infiltrate from the water ponded within the rain garden. A well and lysimeter also were installed in an area believed to represent background conditions that are not influenced by infiltration from the rain garden.

The Chanhassen site (fig. 3) is located within the parking lot of the University of Minnesota Landscape Arboretum. The site is underlain by clay-rich soils derived from glacial till. Consequently, observation wells were not installed. Inflow consisted of runoff from a series of parking lots interspersed with vegetated strips. The inflow was sampled by using a float-activated sampler at the primary point where storm-water runoff enters the rain garden. Overflow samples from this site are unique because they come from a drain tile installed beneath the rain garden. The drain tile empties into a culvert that serves as an overflow during major rainfall events. Data collection from this site was complicated by several factors. Arboretum staff attempted to maintain flowering plants in the rain garden that required frequent watering, which could produce overflow without inflow. The source of this added water was assumed to be the public water supply for the arboretum. In addition, ongoing construction surrounded the site during the sampling period. The effects of construction on runoff loading to the rain garden were not measured during the study.

The Hugo site (fig. 4) is underlain by sand and gravel that is part of the Anoka Sand Plain. Runoff to the rain garden is from the parking lot and from the roof of Hugo City Hall. Other nearby areas also may contribute runoff to the rain garden. Ground water is assumed to flow toward the site from the northwest, an area that consists mostly of gravel roads and athletic fields. The background well and lysimeter are located in this area. No overflow from the rain garden was observed during the study and consequently an overflow sample was not collected.

The Lakeville site (fig. 5) is underlain by a mixture of sandy soils and glacial till. The site was in a state of transition during the study. Much of the contributing drainage area consists of a townhouse development that was under construction throughout the sampling period. The effects of construction on the volume and quality of runoff to the rain garden were not measured during the study. The background observation well and lysimeter were located away from areas of construction, but generally near road rights of way that could influence the quality of water recharged to those monitoring points.

\section{Chanhassen site}
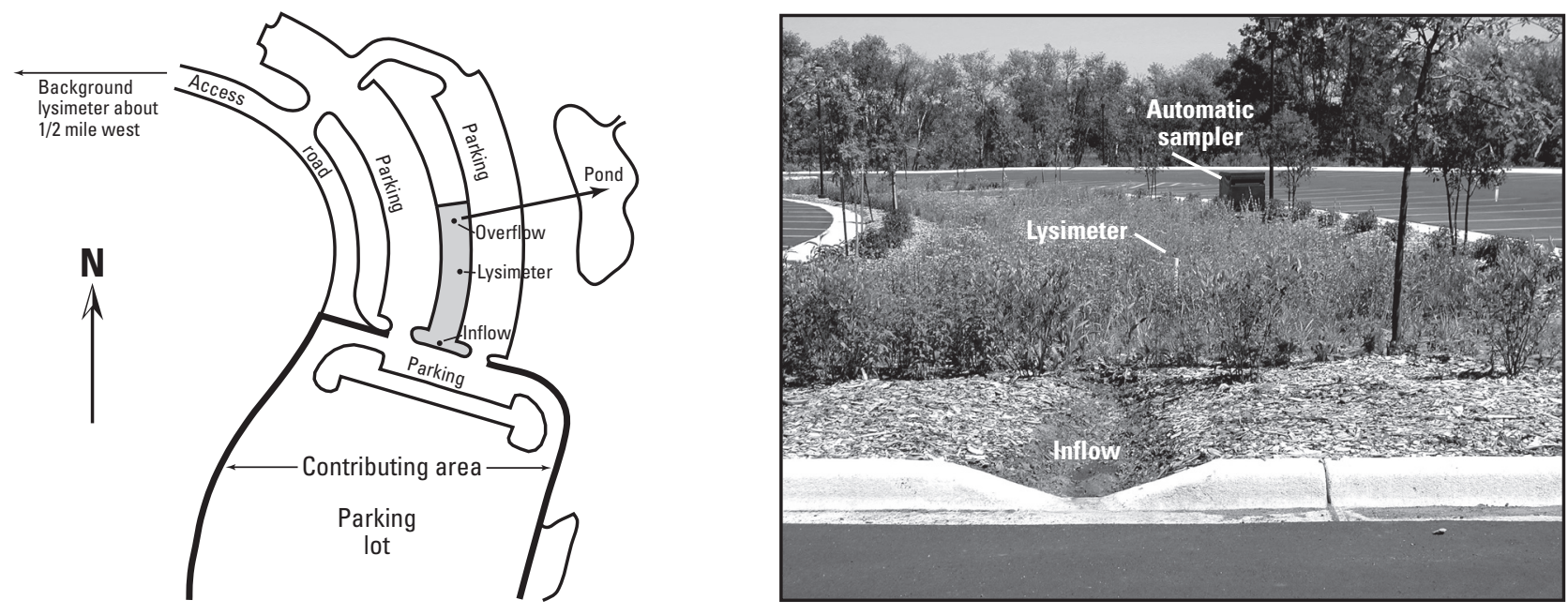

Figure 3. Rain-garden configuration at Chanhassen, Minnesota. 
Table 2. Lithologic log of wells installed at rain-garden sites in the Minneapolis - St. Paul metropolitan area of Minnesota

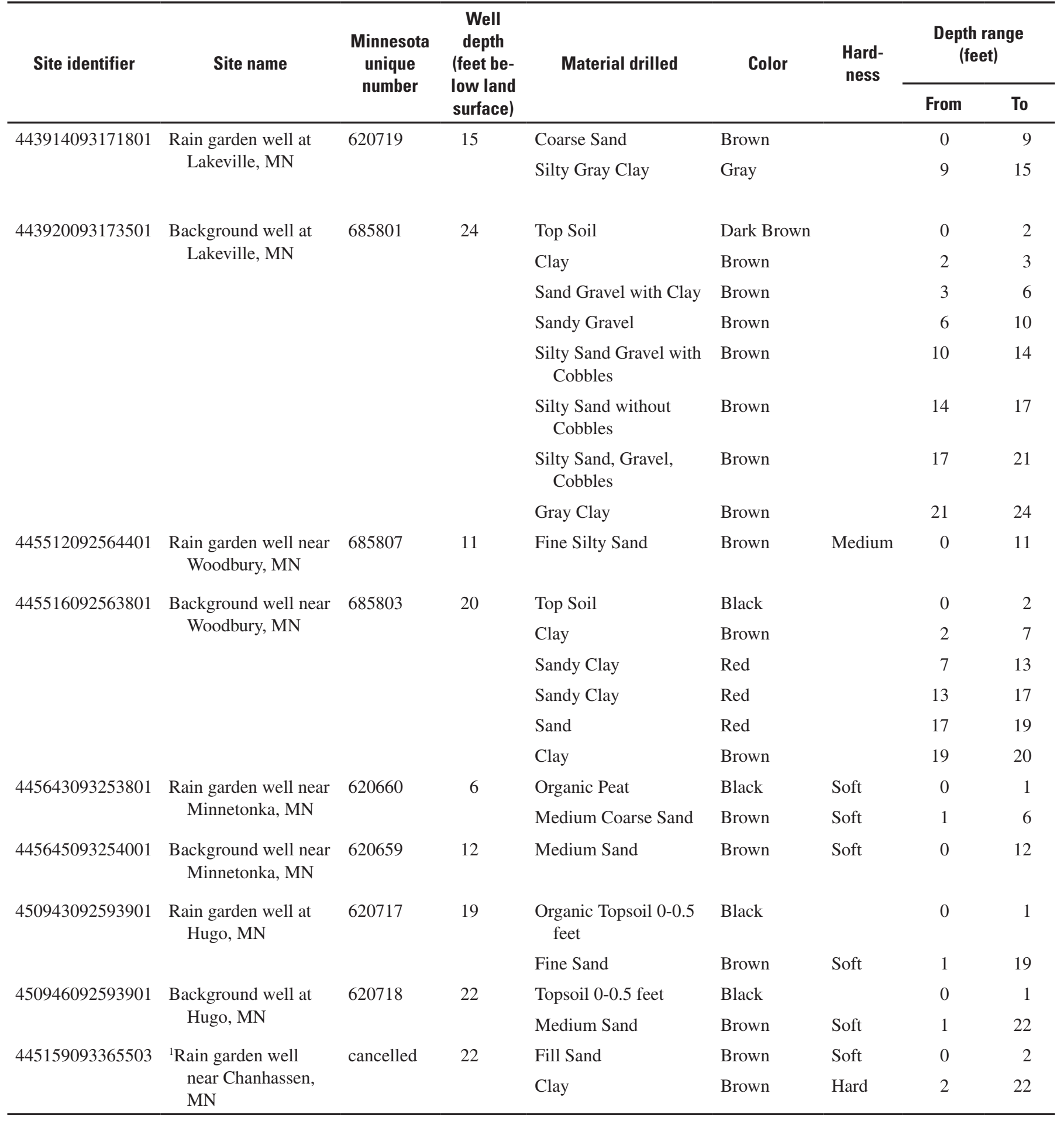

${ }^{1}$ Well was never installed. 

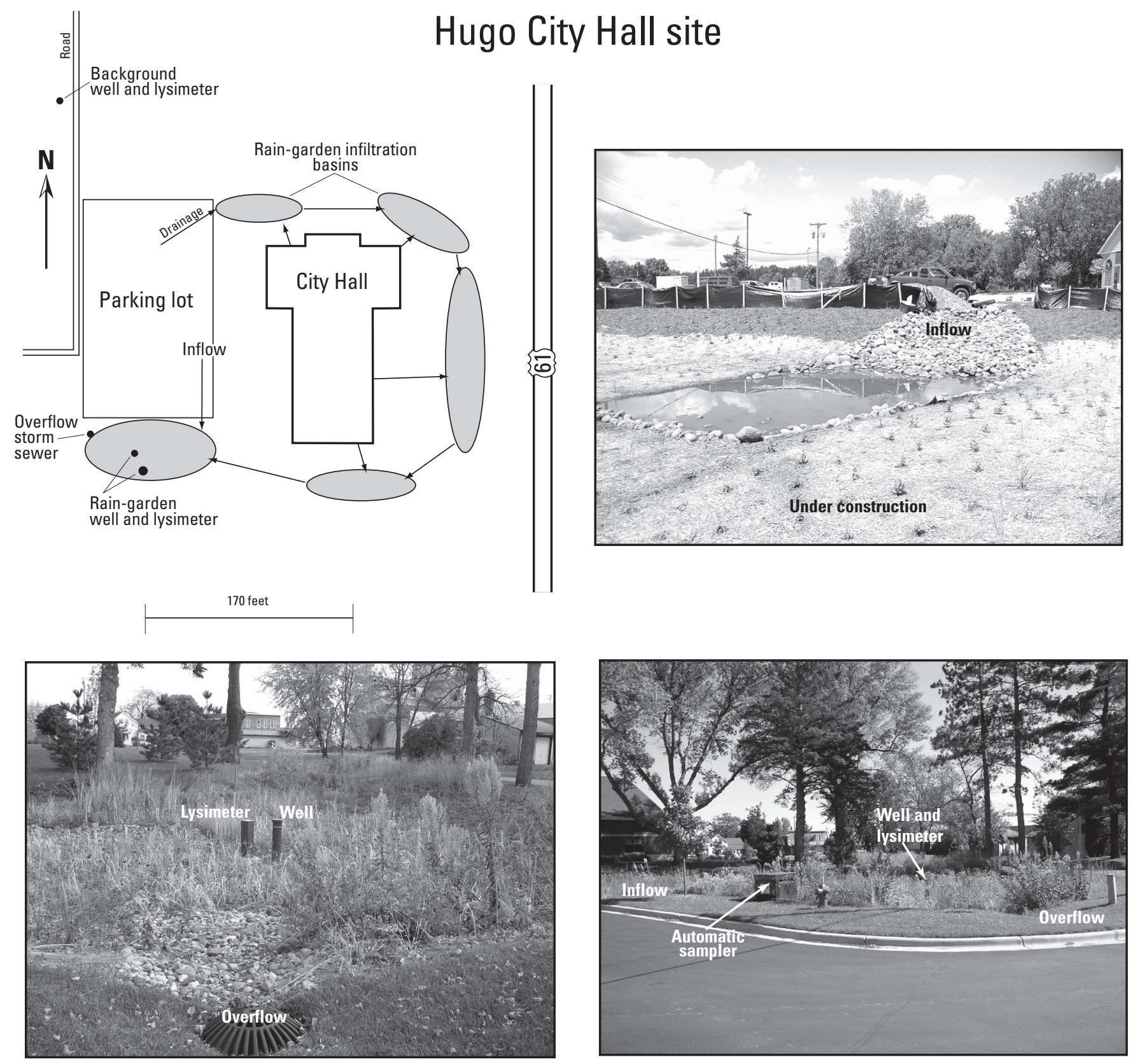

Figure 4. Rain-garden configuration at Hugo, Minnesota. 


\section{Lakeville site}
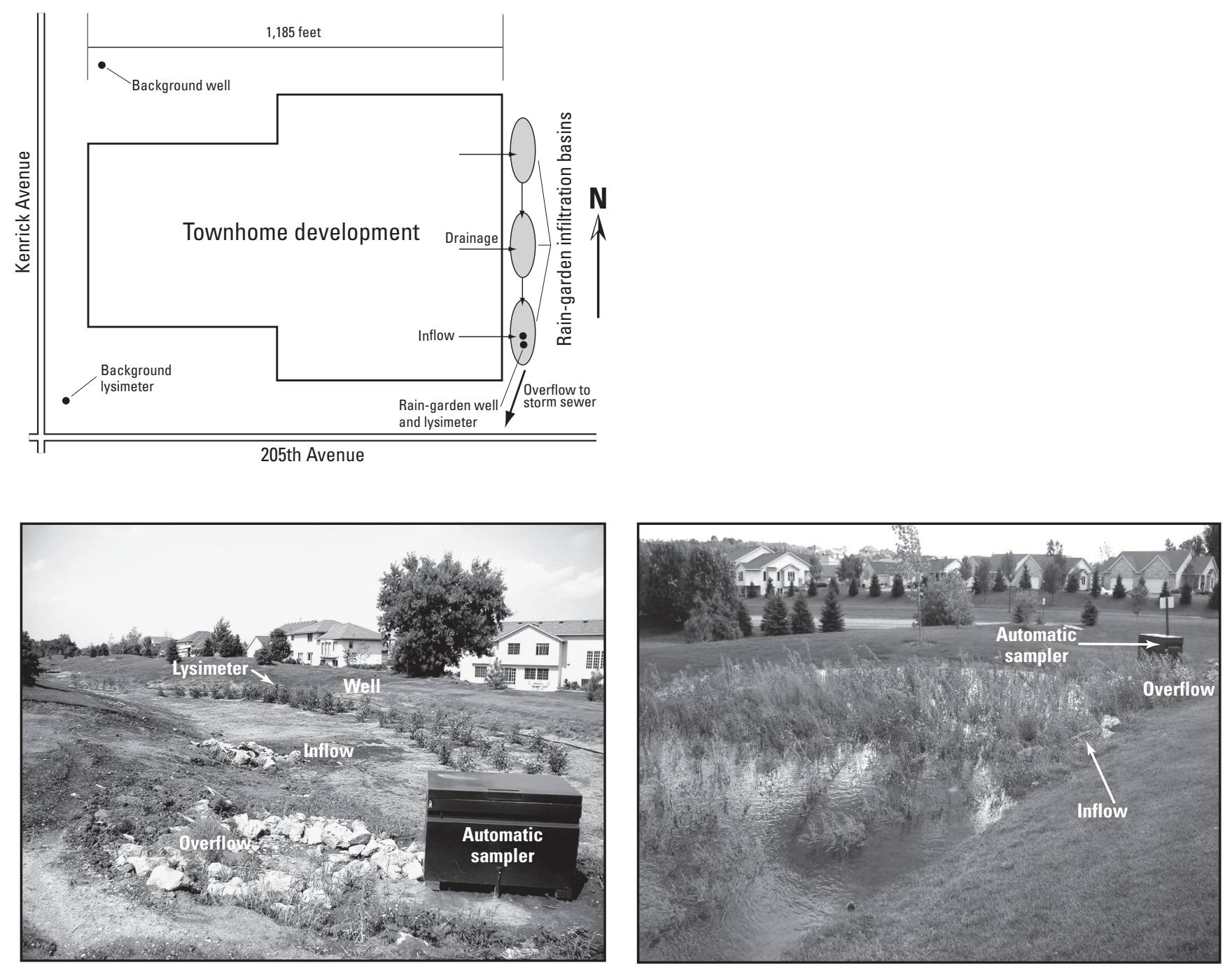

Figure 5. Rain-garden configuration at Lakeville, Minnesota. 


\section{Minnetonka site}
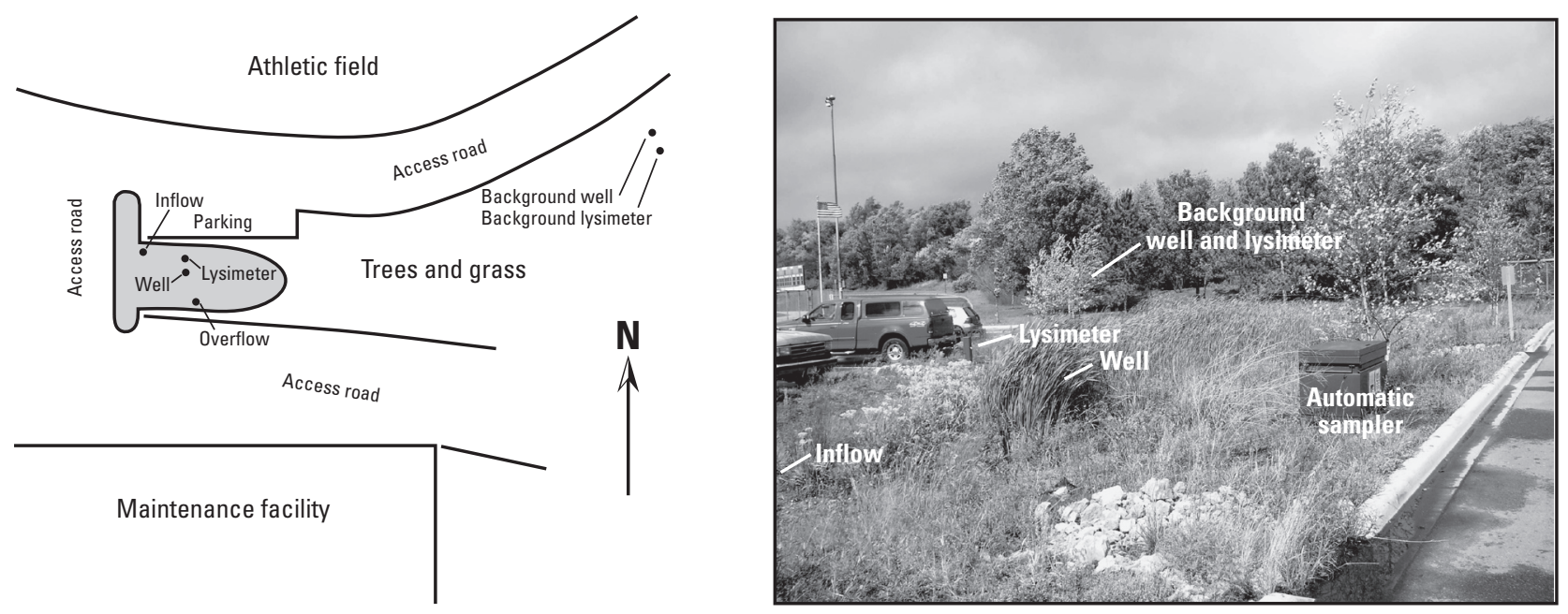

Figure 6. Rain-garden configuration at Minnetonka, Minnesota..

The Minnetonka site (fig. 6) is underlain by soils with a relatively high percentage of clay (fig. 2). Much of the contributing drainage area near the rain garden consists of athletic fields and a maintenance facility. However, the majority of runoff to the site is from general-use parking. This parking inflow was the only one of five inflows to this rain garden that could be routinely sampled because of technical considerations described previously.

The Woodbury site (fig. 7) is underlain by soils with a relatively large percentage of clay (fig. 2). The rain garden receives runoff from nearby roadways, housing developments, and a series of small impoundments. The site was unusual because overflow commonly occurred during periods of little or no runoff, indicating that it was supplied from upstream ponds or ground-water inflow.

\section{Methods}

An idealized concept of sampling points at each site is shown in figure 1 . The installation included inflow and overflow samplers, two ground-water observation wells completed just below the water table, and two soil-moisture lysimeters installed in the unsaturated zone.

Suction lysimeters were installed in the unsaturated zone underlying each rain garden to facilitate collection of infiltration water before it reached the water table. Water-table observation wells were installed near the middle of each rain garden to sample water reaching the underlying aquifer. To provide background (presumably upgradient) chemical information, an additional suction lysimeter and well were installed some distance from the rain garden. Comparison of the chemical data from the surface runoff (inflow) samplers and the suction lysimeters with the data from the water-table wells provides information regarding the attenuation of the chemical con- stituents by the rain garden as well as by the unsaturated zone. The suction lysimeters and water-table wells generally were sampled monthly for indicator constituents during the sampling period, although it was not uncommon for some of these sampling points to have insufficient water for collection and analysis.

Automated samplers were designed to obtain samples of inflow to and overflow from the rain gardens. Samplers were programmed to collect initial runoff and to sample at a reduced frequency as the runoff continued during a rainfall event. One minute after sensing runoff, 1.6 liters of water were collected. An additional 1.6 liters of water were collected after 2 minutes had elapsed since the previous sample, continuing until three samples had been collected. A fourth sample of 0.4 liter was collected after 10 minutes had elapsed since the sampler first was activated by an event. The remaining samples of 0.4 liter each were collected every 5 minutes until all the bottles were filled. If runoff stopped before all the bottles in the sampler were filled, a partial sample was collected. If the runoff continued beyond the capacity of the sampler, that water was not sampled.

Individual site-monitoring installations varied because of conditions specific to each site. Wells were not installed at the Chanhassen site because the subsurface consisted primarily of clay, and wells would not have yielded water. Other complications included delays in site-monitoring installation due to delays in rain-garden construction. Also, some sites were so effective in attenuating runoff, such as the Hugo site, that little or no overflow occurred and few or no samples of overflow were collected.

Wells and lysimeters were installed in a manner consistent with the guidance provided by Wood (1976). Inflow and overflow automatic samplers were installed according to manufacturer's recommendations (Isco, Inc., 1996, instruc- 


\section{Woodbury site}
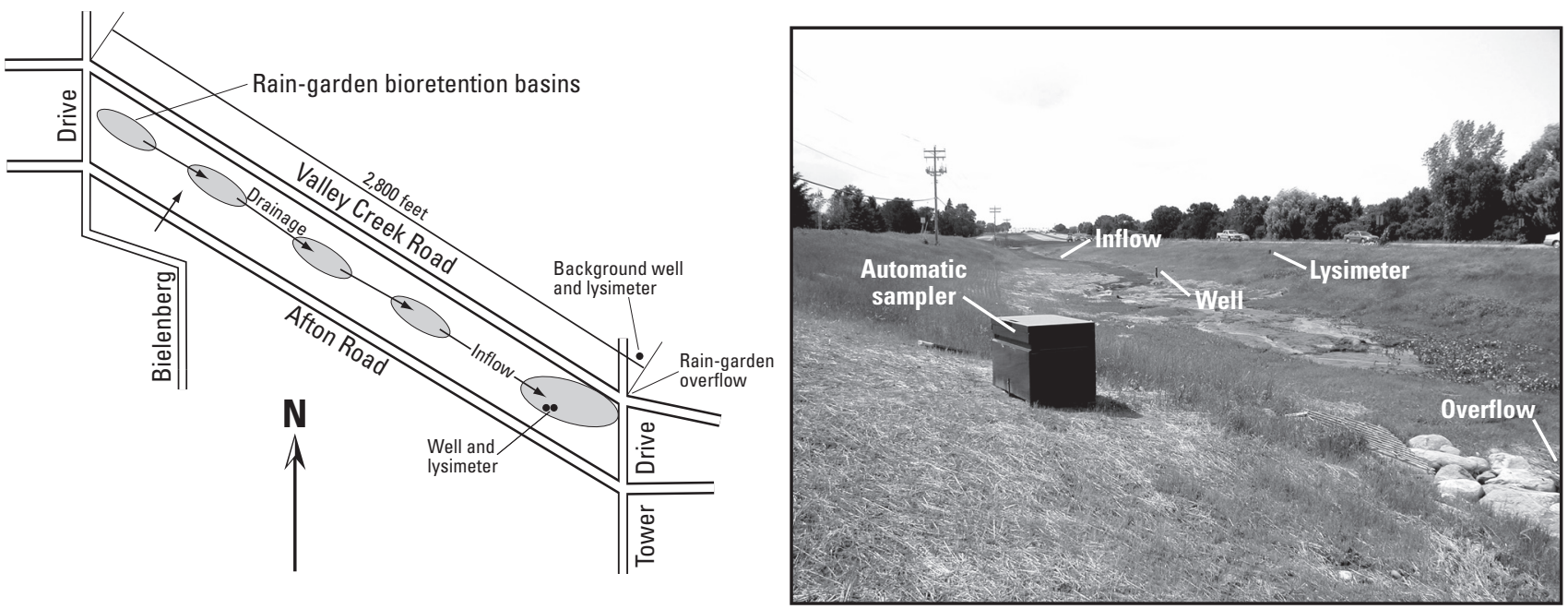

Figure 7. Rain-garden configuration at Woodbury, Minnesota.

tion manual for 3700 portable sampler, 209 p.). Samples were collected and processed by using standard methods developed and published by the USGS. A complete list of the techniques that were adapted to collect and process samples for this study is available as part of the USGS Techniques of WaterResources Investigations publication series (U.S. Geological Survey, variously dated) that can be accessed at $h t t p: / / w a t e r$. usgs.gov/pubs/twri.

Samples collected by the automatic samplers were transported to the USGS Water Science Center of Minnesota and composited into a churn splitter for collection of representative subsamples for analysis. Field values were determined from these subsamples. Water samples were filtered and preserved, and analyzed at the USGS National Water Quality Laboratory using the methods described in Fishman and Friedman (1989). Samples were analyzed for constituents listed in tables 3 through 7.

The data collected for this study are available from two sources, including the annual USGS water-resources data reports (Mitton and others, 2003, 2004, and 2005), which also are published electronically on the USGS Water Science Center of Minnesota website at http://mn.water.usgs.gov. Data also can be retrieved from the USGS National Water Information System website (NWIS-Web) at http://waterdata.usgs. gov/nwis.

The timing of the sampling varied. Some samples were collected early in the study, as the sites were being established and instrumented (table 1). A period of less-than-normal precipitation ensued after the installation that resulted in few or no samples. Although sites were routinely visited, site and weather conditions sometimes prevented collection of water for chemical analysis. In some instances lysimeters were dry and ground-water levels had dropped below the screened interval of the wells because of the extended dry period.
The areal extent of the area of study also resulted in substantial variability in rainfall. Local rainfall sometimes produced deluge conditions at a site while leaving other sites without precipitation. The density of real-time rainfall monitoring was not sufficient to provide adequate information for ideal timing of site visits in several instances.

Approximately 15 percent of all water-quality samples were collected for quality-assurance (duplicates, blanks, splits) purposes. All water-quality samples were collected and analyzed by using the USGS quality-assurance protocols documented at http://water.usgs.gov/owq/quality.html and http://wwwrcolka.cr.usgs.gov/uo/proposals/Tables $1 \& 2 D Q O s$. $p d f$. Coding of water-quality samples followed the procedures documented at http://ar.water.usgs.gov/nawqa/sample-coding/ outline.html.

\section{WATER OUALITY AT RAIN-GARDEN SITES}

Periods without water-quality data resulted from the lack of runoff and recharge that occurs during the winter. Persons were dispatched on several occasions to manually sample snowmelt runoff because the automatic samplers likely would have been damaged by freezing conditions, but water samples rarely were collected. When hydrographers arrived, runoff generally was not sufficient to provide adequate sample volume. Because most of these sites drained roadways or parking lots, any snow or other frozen precipitation that had accumulated typically was pushed or transported to areas where it did not contribute to the inflow of the rain garden.

After the sites had been established and the weather became more conducive to generating runoff, more samples were collected. Substantial variability among the sites resulted 
from differences in site conditions and rain-garden design.

The data allow for general observations about each of the sites and about differences among the individual sites.

Median concentrations for the data collected from all five of the rain-garden sites are shown in tables 3 through 7 . These tables also show the approximate number of each type of constituent measured from each of the media sampled. Individual sample numbers used to compute the median varied depending on a variety of factors, such as availability of adequate water to complete the intended analysis. Water-quality results are summarized in this section.

\section{Chanhassen}

The median specific-conductance value of the overflow at the Chanhassen site was much higher than that of the inflow (table 3). The increase may be attributed to additional, unsampled storm-water runoff from the parking lot and (or) infiltration through the substrate, which leached minerals to the drain tile and was sampled as overflow. Total suspended solids were retained by the rain garden to levels less than the $10 \mathrm{mg} / \mathrm{L}$ method reporting limit for this measurement. The concentration of most nitrogen species measured at the rain-garden overflow decreased by an order of magnitude from that measured at the inflow. The median chloride and dissolved-solids concentration increased from inflow to overflow. Median dissolved phosphorus concentrations generally were similar from inflow to overflow, but median total phosphorus concentrations decreased from inflow to overflow.

The background lysimeter was frequently dry, so few samples were collected from that site. When both background and rain-garden lysimeters were sampled concurrently, $\mathrm{pH}$ and conductance were similar, and nutrient concentrations were similar but near method reporting limits. Concentrations of nitrogen and phosphorus greater than median values in some samples indicate that fertilizers may have been applied to the rain garden during the course of this study.

The soils beneath this site had a high clay content, which precluded installation of monitoring wells. Therefore, no data are available to assess the effects of the Chanhassen rain gardens on ground-water quality.

Data from the Chanhassen site indicate that the chemistry of each sampling site (inflow compared to overflow, and background lysimeter compared to rain-garden lysimeter) converges over time. Throughout much of the study, nitrogen and total phosphorus concentrations were lower in the overflow as compared to the inflow, indicating that the rain garden was assimilating much of the nutrients that might have otherwise been transported to the overflow. Water quality had changed little from inflow to overflow during the most recent sampling visits as determined from measurements of specific conductance, $\mathrm{pH}$, and concentrations of chloride, dissolved solids, and dissolved phosphorus. This indicates that the Chanhassen rain garden may approach a state of equilibrium with respect to quality of inflow and overflow for some constituents.

\section{Hugo}

Samples from several inflow events were collected, but overflow samples never were observed or sampled. This indicates that storage within the rain gardens was adequate to assimilate the inputs, and that infiltration to the subsurface was effective.

Samples from the background and rain-garden lysimeters had similar median values of constituents measured (table 4). Median chloride concentrations in the rain-garden lysimeter were about half those measured in the background, indicating some dilution effect.

The background and rain-garden wells had similar $\mathrm{pH}$ and nutrient concentrations. Chloride concentrations in samples collected from the background and rain-garden wells were

Table 3. Median values of selected physical properties, chemical constituents, and nutrient species of water from the rain-garden site in Chanhassen, Minnesota, 2002-04

[cm, centimeter; mg/L, milligrams per liter; ${ }^{\circ} \mathrm{C}$, degrees Celsius; $\mathrm{N}$, nitrogen; $\mathrm{P}$, phosphorus; $\mathrm{n} / \mathrm{a}$, no samples for that constituent]

\begin{tabular}{|c|c|c|c|c|c|c|c|c|c|c|c|}
\hline $\begin{array}{l}\text { Sample location } \\
\text { (approximate number } \\
\text { of samples; may be } \\
\text { fewer for some } \\
\text { measurements) }\end{array}$ & $\begin{array}{c}\text { pH, } \\
\text { water, } \\
\text { whole, } \\
\text { field } \\
\text { (units) }\end{array}$ & $\begin{array}{c}\text { Specific } \\
\text { conduct- } \\
\text { ance } \\
\text { (micro- } \\
\text { siemens/ } \\
\text { cm at } \\
25^{\circ} \mathrm{C} \text { ) }\end{array}$ & $\begin{array}{c}\text { Chloride } \\
\text { (mg/L as } \\
\text { CI) }\end{array}$ & $\begin{array}{l}\text { Solids, } \\
\text { residue } \\
\text { at } 180 \\
{ }^{\circ} \text { C, dis- } \\
\text { solved } \\
\text { (mg/L) }\end{array}$ & $\begin{array}{c}\text { Residue } \\
\text { total at } \\
105^{\circ} \mathrm{C} \text {, } \\
\text { sus- } \\
\text { pended } \\
\text { (mg/L) }\end{array}$ & $\begin{array}{c}\text { Nitrogen, } \\
\text { am- } \\
\text { monia + } \\
\text { organic, } \\
\text { total } \\
\text { (mg/L as } \\
\mathrm{N} \text { ) }\end{array}$ & $\begin{array}{l}\text { Nitrogen, } \\
\text { ammonia, } \\
\text { dissolved } \\
\text { (mg/L as } \\
\mathrm{N} \text { ) }\end{array}$ & $\begin{array}{l}\text { Nitrogen, } \\
\text { nitrite + } \\
\text { nitrate, } \\
\text { dissolved } \\
\text { (mg/L as } \\
\mathrm{N})\end{array}$ & $\begin{array}{l}\text { Nitrogen, } \\
\text { nitrite, } \\
\text { dis- } \\
\text { solved } \\
\text { (mg/L as } \\
\text { N) }\end{array}$ & $\begin{array}{l}\text { Phos- } \\
\text { phorus, } \\
\text { dis- } \\
\text { solved } \\
\text { (mg/L } \\
\text { as P) }\end{array}$ & $\begin{array}{l}\text { Phos- } \\
\text { phorus, } \\
\text { total } \\
\text { (mg/L } \\
\text { as P) }\end{array}$ \\
\hline Inflow composite (5) & 7.8 & 176 & 3.2 & 198 & 190 & 3.6 & 0.85 & 1.15 & 0.05 & 0.04 & 0.29 \\
\hline Background lysimeter (2) & 7.8 & 725 & $\mathrm{n} / \mathrm{a}$ & $\mathrm{n} / \mathrm{a}$ & $\mathrm{n} / \mathrm{a}$ & .31 & .04 & .06 & .01 & .03 & .03 \\
\hline Background well (0) & $\mathrm{n} / \mathrm{a}$ & $\mathrm{n} / \mathrm{a}$ & $\mathrm{n} / \mathrm{a}$ & $\mathrm{n} / \mathrm{a}$ & $\mathrm{n} / \mathrm{a}$ & $\mathrm{n} / \mathrm{a}$ & $\mathrm{n} / \mathrm{a}$ & $\mathrm{n} / \mathrm{a}$ & $\mathrm{n} / \mathrm{a}$ & $\mathrm{n} / \mathrm{a}$ & $\mathrm{n} / \mathrm{a}$ \\
\hline Rain-garden lysimeter (2) & 7.5 & 645 & 10 & $\mathrm{n} / \mathrm{a}$ & $\mathrm{n} / \mathrm{a}$ & .32 & .04 & .10 & .01 & .06 & .06 \\
\hline Rain-garden well (0) & $\mathrm{n} / \mathrm{a}$ & $\mathrm{n} / \mathrm{a}$ & $\mathrm{n} / \mathrm{a}$ & $\mathrm{n} / \mathrm{a}$ & $\mathrm{n} / \mathrm{a}$ & $\mathrm{n} / \mathrm{a}$ & $\mathrm{n} / \mathrm{a}$ & $\mathrm{n} / \mathrm{a}$ & $\mathrm{n} / \mathrm{a}$ & $\mathrm{n} / \mathrm{a}$ & $\mathrm{n} / \mathrm{a}$ \\
\hline
\end{tabular}


Table 4. Median values of selected physical properties, chemical constituents, and nutrient species of water from the rain-garden site in Hugo, Minnesota, 2002-04

[cm, centimeter; mg/L, milligrams per liter; ${ }^{\circ} \mathrm{C}$, degrees Celsius; $\mathrm{N}$, nitrogen; $\mathrm{P}$, phosphorus; $\mathrm{n} / \mathrm{a}$, no samples for that constituent]

\begin{tabular}{|c|c|c|c|c|c|c|c|c|c|c|c|}
\hline $\begin{array}{l}\text { Sample location } \\
\text { (approximate number } \\
\text { of samples; may be } \\
\text { fewer for some } \\
\text { measurements) }\end{array}$ & $\begin{array}{l}\mathrm{pH}, \\
\text { water, } \\
\text { whole, } \\
\text { field } \\
\text { (units) }\end{array}$ & $\begin{array}{c}\text { Specific } \\
\text { conduct- } \\
\text { ance } \\
\text { (micro- } \\
\text { siemens/ } \\
\text { cm at } \\
25^{\circ} \mathrm{C} \text { ) }\end{array}$ & $\begin{array}{l}\text { Chloride } \\
\text { (mg/L as } \\
\text { CI) }\end{array}$ & $\begin{array}{l}\text { Solids, } \\
\text { residue } \\
\text { at } 180 \\
{ }^{\circ} \text { C, dis- } \\
\text { solved } \\
\text { (mg/L) }\end{array}$ & $\begin{array}{l}\text { Residue } \\
\text { total at } \\
105^{\circ} \mathrm{C} \text {, } \\
\text { sus- } \\
\text { pended } \\
\text { (mg/L) }\end{array}$ & $\begin{array}{c}\text { Nitrogen, } \\
\text { am- } \\
\text { monia + } \\
\text { organic, } \\
\text { total } \\
\text { (mg/L as } \\
\mathrm{N} \text { ) }\end{array}$ & $\begin{array}{l}\text { Nitrogen, } \\
\text { ammonia, } \\
\text { dissolved } \\
\text { (mg/L as } \\
\mathrm{N} \text { ) }\end{array}$ & $\begin{array}{l}\text { Nitrogen, } \\
\text { nitrite + } \\
\text { nitrate, } \\
\text { dissolved } \\
\text { (mg/L as } \\
\mathrm{N} \text { ) }\end{array}$ & $\begin{array}{l}\text { Nitrogen, } \\
\text { nitrite, } \\
\text { dis- } \\
\text { solved } \\
\text { (mg/L as } \\
\mathrm{N} \text { ) }\end{array}$ & $\begin{array}{l}\text { Phos- } \\
\text { phorus, } \\
\text { dis- } \\
\text { solved } \\
\text { (mg/L } \\
\text { as P) }\end{array}$ & $\begin{array}{l}\text { Phos- } \\
\text { phorus, } \\
\text { total } \\
\text { (mg/L } \\
\text { as P) }\end{array}$ \\
\hline Inflow composite $(8)$ & 8.0 & 118 & 3 & 65 & 45.5 & 0.95 & 0.18 & 0.45 & 0.03 & 0.19 & 0.3 \\
\hline Background lysimeter (4) & 9.3 & 174 & 3.3 & $\mathrm{n} / \mathrm{a}$ & $\mathrm{n} / \mathrm{a}$ & .35 & .04 & 2.0 & .01 & .04 & .04 \\
\hline Background well (10) & 6.7 & 213 & 43 & 138 & $\mathrm{n} / \mathrm{a}$ & .11 & .04 & 2.0 & .01 & .07 & .08 \\
\hline Rain-garden lysimeter (7) & 9.2 & 164 & 1.6 & $\mathrm{n} / \mathrm{a}$ & $\mathrm{n} / \mathrm{a}$ & .35 & .04 & 1.28 & .01 & .09 & .07 \\
\hline Rain-garden well (10) & 6.9 & 67.5 & .95 & 56 & $\mathrm{n} / \mathrm{a}$ & .15 & .04 & .79 & .01 & .06 & .06 \\
\hline
\end{tabular}

substantially different and diverged over time, indicating that runoff entering the rain garden may dilute existing concentrations of dissolved salts as recharge is focused on the ground water immediately beneath the rain gardens (G.N. Delin, U.S. Geological Survey, oral commun., 2005). The specific-conductance value in samples from the background well increased during this study and decreased in samples from the rain-garden well. Chloride concentrations showed similar trends to specific conductance during this study.

\section{Lakeville}

Samples from several inflow events were collected, but overflow samples never were observed or sampled. This indicates that storage within the rain gardens was adequate to assimilate the inputs and that infiltration to the subsurface was effective. On one occasion a sample of standing water from the rain garden was collected and is referred to as an overflow sample.

Specific conductance and concentrations of chloride and nutrients (nitrogen and phosphorus species) in inflow generally were low (table 5). A runoff event sampled on July 30 , 2004, had a suspended-solids concentration of $230 \mathrm{mg} / \mathrm{L}$ and concentrations of several nutrients, including ammonia plus organic nitrogen and total phosphorus, that also were the highest measured during this study. Because more conservative components of runoff such as specific conductance and chloride concentration generally did not vary, it is assumed that nutrient-enriched soils exposed during ongoing construction washed into the rain garden during this event.

The rain-garden lysimeter had specific-conductance values and chloride concentrations that were much lower than those measured in the background lysimeter, with nitrogen concentrations generally following the same pattern. However, dissolved and total phosphorus concentrations were slightly higher in the rain-garden lysimeter than in the background lysimeter. During a site visit a hydrographer observed evidence of pesticide application near the rain garden (L. Gryczkowski, U.S. Geological Survey, oral commun., 2005), which might indicate that fertilizers also were applied near the site and eventually seeped into the subsurface.

Water from the background well at Lakeville generally had much higher specific-conductance values and concentrations of chloride and measured forms of nitrogen than were measured in the rain-garden well (table 5). Dissolved and total phosphorus concentrations were comparable in the background and rain-garden wells. The maximum value of phosphorus measured in the rain-garden lysimeter coincided with the maximum measured in the rain garden well.

Other than the peak phosphorus concentrations observed in the rain-garden well and lysimeter during September 2004, no trends were apparent. However, increases during the study period (September 2002 through November 2004) were apparent in the background well and lysimeter. Specific-conductance values and concentrations of chloride and nitrite plus nitrate nitrogen generally increased during this study. The reasons for these increases are not known but could be related to ongoing periods of reduced precipitation with less dilution. They also could be the result of roadway runoff because both background sites are located near heavily used transportation routes.

\section{Minnetonka}

The rain garden in Minnetonka typically had samples of both inflow and overflow. The large volume of runoff (inflow) relative to the size of this rain garden resulted in a relatively short retention time. The field and laboratory water-quality measurements of inflow as compared to overflow provided results that were very similar during concurrent samplings. The rain garden frequently retained water, indicating that infiltration to the ground-water system was limited. Determination of the soil characteristics beneath this rain garden might indicate whether drainage is adequate. The layer of organic 
Table 5. Median values of selected physical properties, chemical constituents, and nutrient species of water from the rain-garden site in Lakeville, Minnesota, 2002-04

[cm, centimeter; $\mathrm{mg} / \mathrm{L}$, milligrams per liter; ${ }^{\circ} \mathrm{C}$, degrees Celsius; $\mathrm{N}$, nitrogen; $\mathrm{P}$, phosphorus; $\mathrm{n} / \mathrm{a}$, no samples for that constituent]

\begin{tabular}{|c|c|c|c|c|c|c|c|c|c|c|c|}
\hline $\begin{array}{l}\text { Sample location } \\
\text { (approximate number } \\
\text { of samples; may be } \\
\text { fewer for some } \\
\text { measurements) }\end{array}$ & $\begin{array}{c}\text { pH, } \\
\text { water, } \\
\text { whole, } \\
\text { field } \\
\text { (units) }\end{array}$ & $\begin{array}{c}\text { Specific } \\
\text { conduct- } \\
\text { ance } \\
\text { (micro- } \\
\text { siemens/ } \\
\mathrm{cm} \text { at } \\
25^{\circ} \mathrm{C} \text { ) }\end{array}$ & $\begin{array}{c}\text { Chlo- } \\
\text { ride } \\
\text { (mg/L } \\
\text { as CI) }\end{array}$ & $\begin{array}{l}\text { Solids, } \\
\text { residue } \\
\text { at } 180 \\
{ }^{\circ} \mathrm{C} \text {, dis- } \\
\text { solved } \\
\text { (mg/L) }\end{array}$ & $\begin{array}{c}\text { Residue } \\
\text { total at } \\
105^{\circ} \mathrm{C}, \\
\text { sus- } \\
\text { pended } \\
\text { (mg/L) }\end{array}$ & $\begin{array}{c}\text { Nitrogen, } \\
\text { am- } \\
\text { monia + } \\
\text { organic, } \\
\text { total } \\
\text { (mg/L as } \\
\mathrm{N} \text { ) }\end{array}$ & $\begin{array}{l}\text { Nitrogen, } \\
\text { ammonia, } \\
\text { dissolved } \\
\text { (mg/L as } \\
\mathrm{N})\end{array}$ & $\begin{array}{c}\text { Nitrogen, } \\
\text { nitrite + } \\
\text { nitrate, } \\
\text { dissolved } \\
\text { (mg/L as } \\
\text { N) }\end{array}$ & $\begin{array}{l}\text { Nitrogen, } \\
\text { nitrite, } \\
\text { dis- } \\
\text { solved } \\
\text { (mg/L as } \\
\text { N) }\end{array}$ & $\begin{array}{l}\text { Phos- } \\
\text { phorus, } \\
\text { dis- } \\
\text { solved } \\
\text { (mg/L } \\
\text { as P) }\end{array}$ & $\begin{array}{c}\text { Phos- } \\
\text { phorus, } \\
\text { total } \\
\text { (mg/L } \\
\text { as P) }\end{array}$ \\
\hline Inflow composite (6) & 7.4 & 99 & 1.6 & 95.5 & 14 & 1.3 & 0.23 & 0.32 & 0.02 & 0.15 & 0.20 \\
\hline Background lysimeter (8) & 8.1 & 2,980 & 24 & $\mathrm{n} / \mathrm{a}$ & $\mathrm{n} / \mathrm{a}$ & 1.1 & .04 & 9.40 & .01 & .1 & .09 \\
\hline Background well (10) & 7.0 & 1,850 & 310 & 661 & $\mathrm{n} / \mathrm{a}$ & .26 & .04 & 3.9 & .01 & .04 & .04 \\
\hline $\begin{array}{l}\text { Rain-garden lysimeter } \\
\text { (10) }\end{array}$ & 8.4 & 298 & 2 & $\mathrm{n} / \mathrm{a}$ & $\mathrm{n} / \mathrm{a}$ & .33 & .04 & 1.6 & .01 & .14 & .13 \\
\hline
\end{tabular}

peat shown in the well log (table 2) at the point where the observation well was installed would reduce infiltration if it covered the bottom of the rain garden.

Median values of specific conductance and concentrations of chloride and dissolved solids at the Minnetonka site were greater in the overflow as compared to the inflow (table 6). This may be the result of evapotranspiration in the rain garden or inflow from contributing areas that were not sampled for this study, but were sampled as part of the overflow that combined water from several inflow sources.

The concentration of suspended solids and most nitrogen compounds was less in overflow as compared to inflow, indicating sedimentation, dilution, or uptake or attenuation by vegetation. The median concentration of total and dissolved phosphorus was similar in inflow and overflow.

The background lysimeter at this site yielded only one sample sufficient to provide water for analysis, and that was only enough to provide partial results. That sample had a specific-conductance value of $2,110 \mu \mathrm{S} / \mathrm{cm}$. The rain-garden lysimeter generally yielded sufficient water for most analyses and had lower specific-conductance values and nutrient concentrations as compared to those values measured in the background lysimeter.

The background well at this site had nutrient concentrations that generally were low and often near the detection limit. However, much of the nitrogen measured was in the form of nitrate nitrogen (the nitrite concentration was negligible), with concentrations that ranged from 2.8 to $6.6 \mathrm{mg} / \mathrm{L}$ with a median of $5.72 \mathrm{mg} / \mathrm{L}$. Although this is predominantly a residential area, these concentrations could be indicative of fertilizer inputs in agricultural regions that have permeable soils (Hanson, 1998).

One complete analysis and one partial analysis were done (because of insufficient water collected from the well)

Table 6. Median values of selected physical properties, chemical constituents, and nutrient species of water from the rain-garden site in Minnetonka, Minnesota, 2002-04

[cm, centimeter; mg/L, milligrams per liter; ${ }^{\circ} \mathrm{C}$, degrees Celsius; N, nitrogen; P, phosphorus; n/a, no samples for that constituent]

\begin{tabular}{|c|c|c|c|c|c|c|c|c|c|c|c|}
\hline $\begin{array}{l}\text { Sample location } \\
\text { (approximate number } \\
\text { of samples; may be } \\
\text { fewer for some } \\
\text { measurements) }\end{array}$ & $\begin{array}{c}\text { pH, } \\
\text { water, } \\
\text { whole, } \\
\text { field } \\
\text { (units) }\end{array}$ & $\begin{array}{c}\text { Specific } \\
\text { conduct- } \\
\text { ance } \\
\text { (micro- } \\
\text { siemens/ } \\
\mathrm{cm} \text { at } \\
25^{\circ} \mathrm{C} \text { ) }\end{array}$ & $\begin{array}{c}\text { Chlo- } \\
\text { ride } \\
\text { (mg/L } \\
\text { as Cl) }\end{array}$ & $\begin{array}{c}\text { Solids, } \\
\text { residue } \\
\text { at } 180 \\
{ }^{\circ} \mathrm{C} \text {, dis- } \\
\text { solved } \\
\text { (mg/L) }\end{array}$ & $\begin{array}{l}\text { Residue } \\
\text { total at } \\
105^{\circ} \mathrm{C} \text {, } \\
\text { sus- } \\
\text { pended } \\
\text { (mg/L) }\end{array}$ & $\begin{array}{c}\text { Nitrogen, } \\
\text { am- } \\
\text { monia + } \\
\text { organic, } \\
\text { total } \\
\text { (mg/L as } \\
\mathrm{N} \text { ) }\end{array}$ & $\begin{array}{l}\text { Nitrogen, } \\
\text { ammonia, } \\
\text { dissolved } \\
\text { (mg/L as } \\
\mathrm{N} \text { ) }\end{array}$ & $\begin{array}{l}\text { Nitrogen, } \\
\text { nitrite + } \\
\text { nitrate, } \\
\text { dissolved } \\
\text { (mg/L as } \\
\mathrm{N} \text { ) }\end{array}$ & $\begin{array}{l}\text { Nitrogen, } \\
\text { nitrite, } \\
\text { dis- } \\
\text { solved } \\
\text { (mg/L as } \\
\mathrm{N} \text { ) }\end{array}$ & $\begin{array}{l}\text { Phos- } \\
\text { phorus, } \\
\text { dis- } \\
\text { solved } \\
\text { (mg/L } \\
\text { as P) }\end{array}$ & $\begin{array}{c}\text { Phos- } \\
\text { phorus, } \\
\text { total } \\
\text { (mg/L } \\
\text { as P) }\end{array}$ \\
\hline Inflow composite (9) & 7.9 & 134 & 9.6 & 134 & 172 & 2.4 & 0.45 & 0.59 & 0.03 & 0.13 & 0.34 \\
\hline Overflow composite (6) & 8.1 & 270 & 17 & 183 & 66 & 1.9 & .13 & .46 & .04 & .14 & .35 \\
\hline Background lysimeter (1) & 8.0 & 2,110 & $\mathrm{n} / \mathrm{a}$ & $\mathrm{n} / \mathrm{a}$ & $\mathrm{n} / \mathrm{a}$ & 4.2 & $\mathrm{n} / \mathrm{a}$ & $\mathrm{n} / \mathrm{a}$ & $\mathrm{n} / \mathrm{a}$ & $\mathrm{n} / \mathrm{a}$ & .14 \\
\hline Background well (8) & 7.5 & 574 & 8.4 & $\mathrm{n} / \mathrm{a}$ & $\mathrm{n} / \mathrm{a}$ & .35 & .04 & 5.72 & .01 & .04 & .04 \\
\hline Rain-garden lysimeter (7) & 8.2 & 964 & 44 & $\mathrm{n} / \mathrm{a}$ & $\mathrm{n} / \mathrm{a}$ & .92 & .04 & 1.13 & .01 & .07 & .08 \\
\hline Rain-garden well (1) & 12.1 & 1,940 & 21 & $\mathrm{n} / \mathrm{a}$ & $\mathrm{n} / \mathrm{a}$ & $\mathrm{n} / \mathrm{a}$ & .53 & 1.15 & .54 & .04 & .09 \\
\hline
\end{tabular}


in the rain garden used for this study. In those samples, the specific-conductance values and chloride concentrations were relatively high as compared to water from wells at other sites sampled for this study.

\section{Woodbury}

The rain garden in Woodbury typically had paired samples of both inflow and overflow. Median values of constituents measured in inflow generally were lower as compared to overflow, including specific conductance, chloride, and dissolved solids (table 7). This could result from evapotranspiration in the series of ponds contributing to the rain garden or from other inflow sources that were not sampled. Some inflows were not sampled for this study, but one overflow combined water from these different sources. Suspended solids and nutrient concentrations were lower in overflow as compared to inflow indicating sedimentation, a dilution effect, or uptake by vegetation. Suspended solids and ammonia concentrations were reduced by at least an order of magnitude between sampled inflow and overflow.

The background lysimeter was sampled only once during this study because it was dry during other visits. The lysimeter in the rain garden was sampled five times. Concentrations of nitrogen in the rain-garden lysimeter samples generally declined during this study.

Eight concurrent samples were collected from the background and rain-garden wells. Specific conductance generally increased over time in the background well while it generally decreased in the rain-garden well. Chloride concentrations followed a similar temporal pattern. Nitrogen concentrations generally were too low to discern trends with any confidence.

\section{EFFECTS OF RAIN GARDENS ON WATER OUALITY}

Rain gardens are designed to encourage infiltration while allowing overflow during large runoff events. When subsurface flow conditions are stable and little flow occurs, the ground-water chemistry beneath the rain garden might be expected to approach that of recharge from the rain garden. Determining subsurface flow was beyond the scope of this study.

Some of the effects of rain-garden processes on water quality are shown in figure 8.

- Comparison of specific conductance and chloride concentration of inflow to overflow provides mixed results. Differences appear to depend on degree of infiltration as related to permeability. Permeability is related to the relative amount of clay in the soil; however, the percentage of clay can be a localized condition that likely would require a local site assessment to measure permeability and determine whether the desired infiltration relative to runoff inputs can be achieved and maintained. The lithologic logs (table 2) provide some indication of the soil conditions at the point where the observation well was installed.

- Suspended solids and many related constituent concentrations, including nutrients, are consistently reduced in overflow as compared to inflow.

- The size and contribution of storm-water sources relative to the design of the rain garden needs to be assessed by managers designing and installing these systems. Based on information collected for this study, a wide variety of sites have been selected, built, and designed, but they are not all equally effective at reducing overflow to other receiving waters or at enhancing

Table 7. Median values of selected physical properties, chemical constituents, and nutrient species of water from the rain-garden site in Woodbury, Minnesota, 2002-04

[cm, centimeter; mg/L, milligrams per liter; ${ }^{\circ} \mathrm{C}$, degrees Celsius; $\mathrm{N}$, nitrogen; $\mathrm{P}$, phosphorus; n/a, no samples for that constituent]

\begin{tabular}{|c|c|c|c|c|c|c|c|c|c|c|c|}
\hline $\begin{array}{l}\text { Sample location } \\
\text { (approximate number } \\
\text { of samples; may be } \\
\text { fewer for some } \\
\text { measurements) }\end{array}$ & $\begin{array}{c}\text { pH, } \\
\text { water, } \\
\text { whole, } \\
\text { field } \\
\text { (units) }\end{array}$ & $\begin{array}{c}\text { Specific } \\
\text { conduct- } \\
\text { ance } \\
\text { (micro- } \\
\text { siemens/ } \\
\text { cm at } \\
25^{\circ} \mathrm{C} \text { ) }\end{array}$ & $\begin{array}{c}\text { Chloride } \\
\text { (mg/L as } \\
\text { CI) }\end{array}$ & $\begin{array}{l}\text { Solids, } \\
\text { residue } \\
\text { at } 180 \\
{ }^{\circ} \mathrm{C} \text {, dis- } \\
\text { solved } \\
\text { (mg/L) }\end{array}$ & $\begin{array}{l}\text { Residue } \\
\text { total at } \\
105^{\circ} \mathrm{C} \text {, } \\
\text { sus- } \\
\text { pended } \\
\text { (mg/L) }\end{array}$ & $\begin{array}{c}\text { Nitrogen, } \\
\text { am- } \\
\text { monia + } \\
\text { organic, } \\
\text { total } \\
\text { (mg/L as } \\
\mathrm{N} \text { ) }\end{array}$ & $\begin{array}{l}\text { Nitrogen, } \\
\text { ammonia, } \\
\text { dissolved } \\
\text { (mg/L as } \\
\mathrm{N} \text { ) }\end{array}$ & $\begin{array}{l}\text { Nitrogen, } \\
\text { nitrite + } \\
\text { nitrate, } \\
\text { dissolved } \\
\text { (mg/L as } \\
\mathrm{N} \text { ) }\end{array}$ & $\begin{array}{l}\text { Nitrogen, } \\
\text { nitrite, } \\
\text { dis- } \\
\text { solved } \\
\text { (mg/L as } \\
\mathrm{N} \text { ) }\end{array}$ & $\begin{array}{l}\text { Phos- } \\
\text { phorus, } \\
\text { dis- } \\
\text { solved } \\
\text { (mg/L } \\
\text { as } \mathrm{P} \text { ) }\end{array}$ & $\begin{array}{l}\text { Phos- } \\
\text { phorus, } \\
\text { total } \\
\text { (mg/L } \\
\text { as P) }\end{array}$ \\
\hline Inflow composite (8) & 7.3 & 125 & 15 & 161 & 138 & 4.6 & 0.80 & 1.08 & 0.07 & 0.22 & 0.71 \\
\hline Overflow composite (6) & 7.6 & 309 & 33 & 174 & 12 & .86 & .04 & .42 & .01 & .1 & .14 \\
\hline Background lysimeter (1) & $\mathrm{n} / \mathrm{a}$ & 422 & 32 & $\mathrm{n} / \mathrm{a}$ & $\mathrm{n} / \mathrm{a}$ & .3 & .07 & .37 & .01 & .04 & .04 \\
\hline Background well (9) & 7.1 & 1,190 & 247 & $\mathrm{n} / \mathrm{a}$ & $\mathrm{n} / \mathrm{a}$ & .11 & .04 & .55 & .01 & .03 & .05 \\
\hline Rain-garden lysimeter (5) & 7.6 & 2,680 & 505 & $\mathrm{n} / \mathrm{a}$ & $\mathrm{n} / \mathrm{a}$ & .63 & .05 & .09 & .01 & .05 & .05 \\
\hline Rain-garden well (9) & 7.6 & 359 & 35 & 176 & $\mathrm{n} / \mathrm{a}$ & .54 & .04 & .06 & .01 & .04 & .07 \\
\hline
\end{tabular}



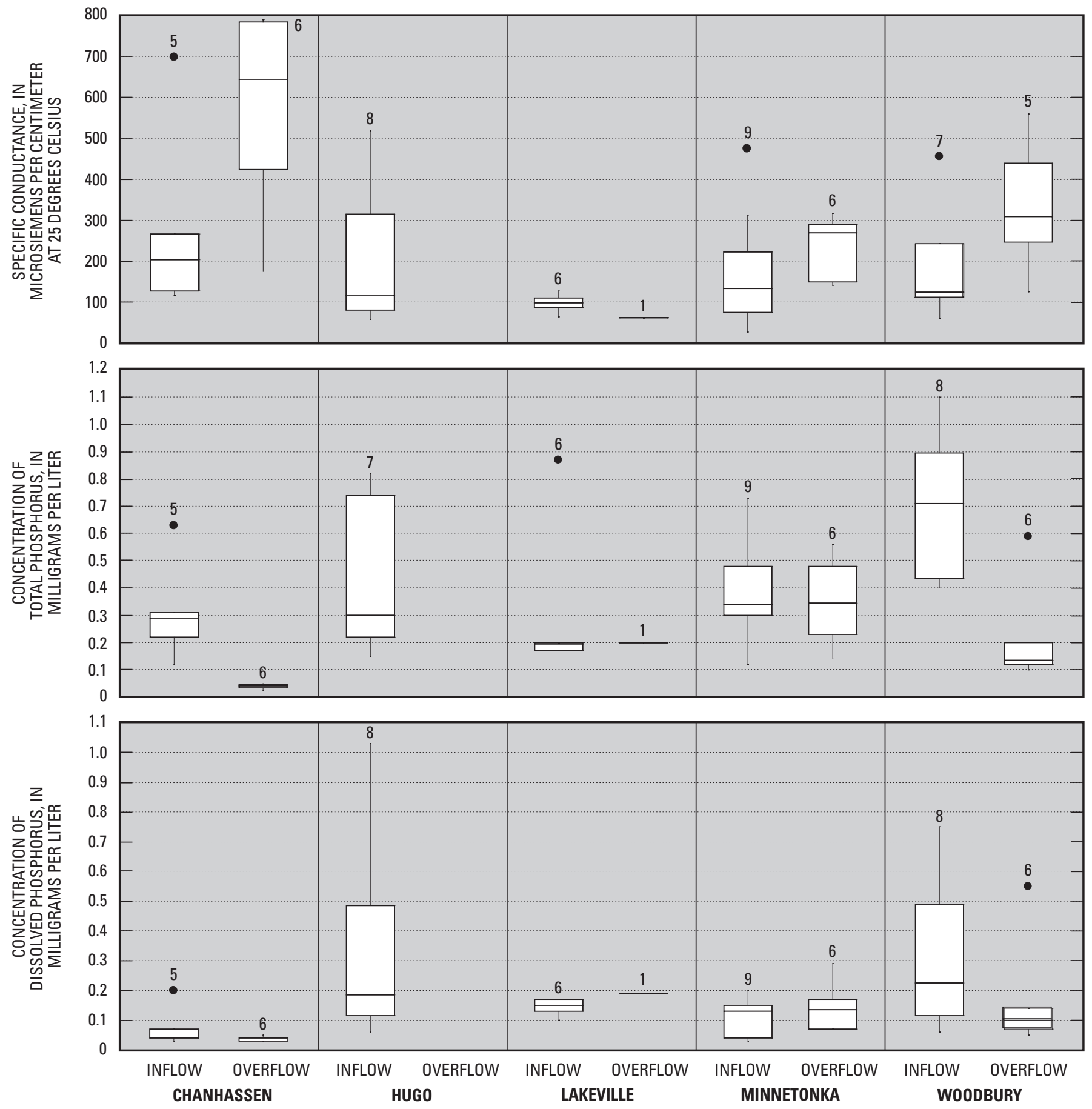

Figure 8. Distribution of specific conductance and phosphorus, chloride, and suspended-solids concentration at each of the five rain-garden sites sampled in the Minneapolis-St. Paul metropolitan area of Minnesota, 2004-04. 

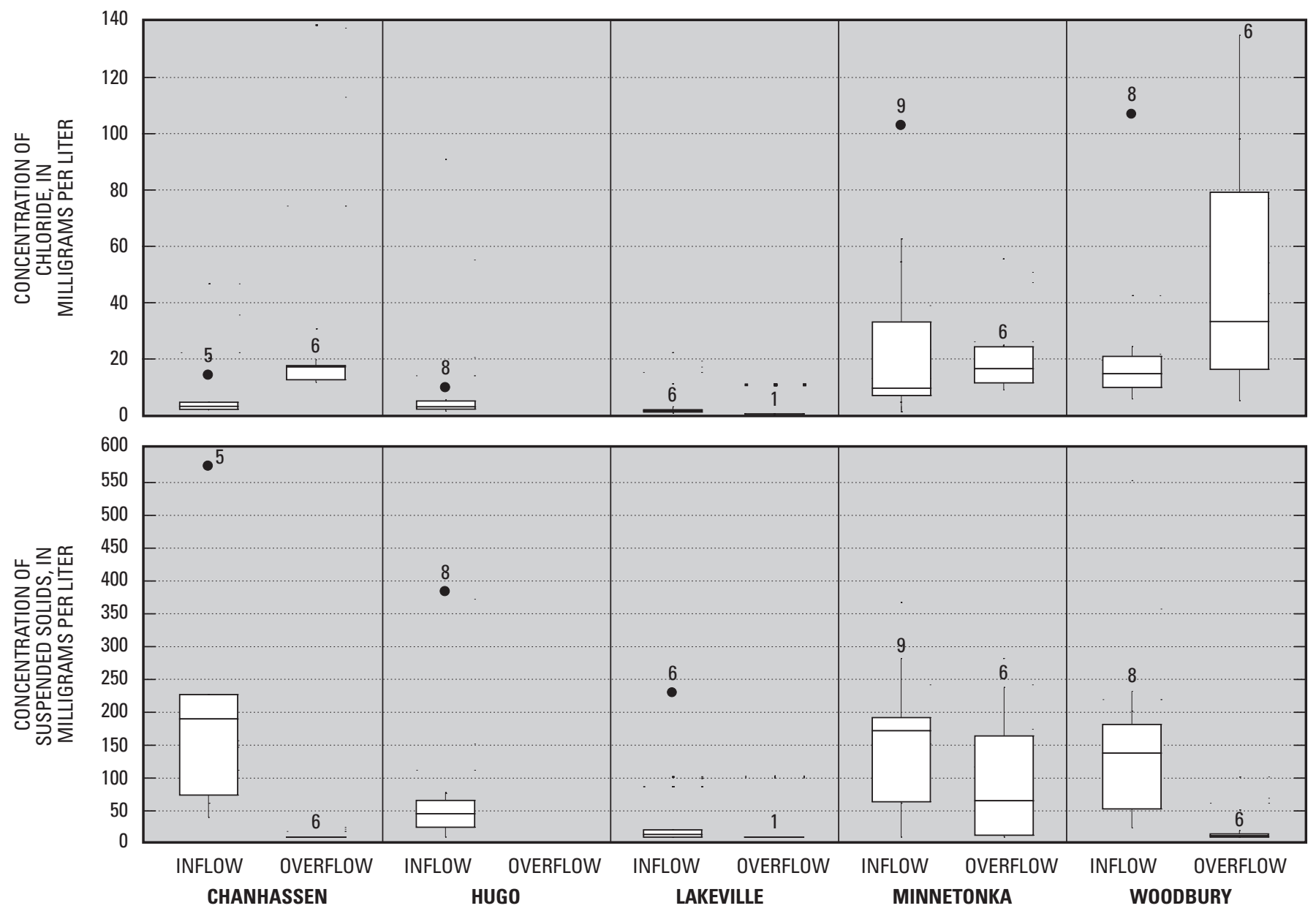

\section{EXPLANATION}

\begin{tabular}{|c|c|}
\hline 6 & $\begin{array}{l}\text { Number of samples } \\
\text { Outlier } \\
+1.5 \text { Interquartile range }\end{array}$ \\
\hline & 75th Percentile \\
\hline & Median \\
\hline & $\begin{array}{l}\text { 25th Percentile } \\
-1.5 \text { Interquartile range }\end{array}$ \\
\hline
\end{tabular}

Figure 8. Distribution of specific conductance and phosphorus, chloride, and suspended-solids concentration at each of the five rain-garden sites sampled in the Minneapolis-St. Paul metropolitan area of Minnesota, 2002-04-Continued. 
infiltration. This study indicates that much of this inequality is related to soil properties within each individual rain garden. Sandy or gravelly soils appear to encourage infiltration to the subsurface, whereas less permeable, clayey soils allow more overflow to downstream waters. It has not been determined whether these conditions will change as vegetation penetrates into the clayey soils or sedimentation clogs permeable soils.

- Based on data collected for this study, there are no consistent trends related to changes in phosphorus concentrations in surface water, although total phosphorus concentrations generally were lower in overflow than in inflow. More information relating to the effect of rain gardens as they mature might help in understanding this aspect of the systems.

- Specific conductance and chloride concentration measured in inflow and in rain-garden wells generally was lower than what was measured in background wells and lysimeters. This indicates that ground waters beneath some rain gardens are diluted by runoff as a result of focused recharge (G.N. Delin, U.S. Geological Survey, oral commun., 2005).

Median specific-conductance values and chloride concentrations measured in rain-garden inflow and rain-garden wells in 2004 are shown in table 8. Because inflow and groundwater quality probably were not in equilibrium during the early part of this study, only results during the last sampling year (2004) are listed.

Table 8. Median specific-conductance value and chloride concentration at each of the five rain-garden sites in the MinneapolisSt. Paul metropolitan area of Minnesota, 2004

$\left[\mu \mathrm{S} / \mathrm{cm}\right.$, microsiemens per centimeter; ${ }^{\circ} \mathrm{C}$, degrees Celsius; $\mathrm{mg} / \mathrm{L}$, milligrams per liter]

\begin{tabular}{lcccc}
\hline Site & $\begin{array}{c}\text { Specific } \\
\text { conduc- } \\
\text { tance, } \\
\text { inflow } \\
(\boldsymbol{\mu S} / \mathbf{c m} \text { at } \\
\left.\mathbf{2 5}^{\circ} \mathbf{C}\right)\end{array}$ & $\begin{array}{c}\text { Chlo- } \\
\text { ride, } \\
\text { inflow } \\
(\mathbf{m g} / \mathbf{L})\end{array}$ & $\begin{array}{c}\text { Specific } \\
\text { conduc- } \\
\text { tance, } \\
\text { rain-garden } \\
\text { well } \\
(\boldsymbol{\mu S} / \mathbf{c m} \\
\text { at 25) }\end{array}$ & $\begin{array}{c}\text { Chloride, } \\
\text { rain- } \\
\text { garden } \\
\text { well } \\
(\mathbf{m g} / \mathbf{L})\end{array}$ \\
\hline Chanhassen & 176 & 3.2 & No well & No well \\
Hugo & 118 & 3.0 & 68 & 1.0 \\
Lakeville & 99 & 1.6 & 307 & 5.9 \\
Minnetonka & 134 & 9.6 & 1,935 & 21 \\
Woodbury & 125 & 15 & 359 & 35 \\
\hline
\end{tabular}

The distribution of specific conductance measured at the inflow as compared to values measured in subsurface waters of the rain garden is shown in figure 9. These data encompass the entire period of data collection.
There was little similarity in specific-conductance values among the inflow and ground-water samples collected from the rain gardens, which indicates that other factors have a greater influence on the ground-water chemistry than infiltration. The most similar values were measured at Hugo, but the specific-conductance value was far less than the values measured from inflow. Although this could indicate that other factors are influencing the ground-water chemistry at Hugo, it is possible that not all of the inflow was sampled during extended runoff events and that continued, unsampled inflow contributed water that further diluted the ground water. Several factors may be involved that could vary at each rain garden. Ground-water flow, which was not assessed for this study, may overwhelm any evidence of recharge from the rain garden. Evapotranspiration from the rain garden may concentrate constituents before they enter the ground-water system through recharge. Infiltration through the unsaturated zone may be leaching minerals (salts) that could continue until some equilibrium is reached between recharge waters and subsurface moisture.

Temporal plots of the data collected from the rain-garden sites at Hugo (the site showing the most effective infiltration of runoff and no observed overflow) and Woodbury (a site having frequent overflow) are shown in figure 10. The infiltration characteristics at these two sites indicate that they may represent the extremes of sites measured for this study. All of the results show considerable variability, but some generalizations may be made.

There is a general decline in chloride and nitrite plus nitrate nitrogen concentrations at the Hugo rain-garden site relative to background conditions. The large variability of results at the rain-garden site located in Woodbury make it difficult to determine what trends are evident among the media sampled.

\section{IMPLICATIONS OF RESULTS}

The rain gardens selected for this study provided a wide range of climate, geomorphic, and engineering designs around the Minneapolis-St. Paul metropolitan area, which resulted in a broad range of water-quality results. In all cases the rain gardens were installed to accept runoff from impervious surfaces including paved roadways and parking lots, rooftops, and other surfaces. Rather than convey the water to ditches, creeks, and rivers downstream, they are intended to keep the runoff close to where it originates and encourage infiltration and recharge to the local ground-water system.

The USGS installed the monitoring equipment and sampled the sites, and other entities designed the rain gardens. Factors such as contributing drainage area, frequency and duration of storm events, design capacity of the rain garden to store runoff and enhance infiltration before overflow, vegetation type, and the material used to construct the rain-garden bottom all can affect infiltration and the resulting water qual- 


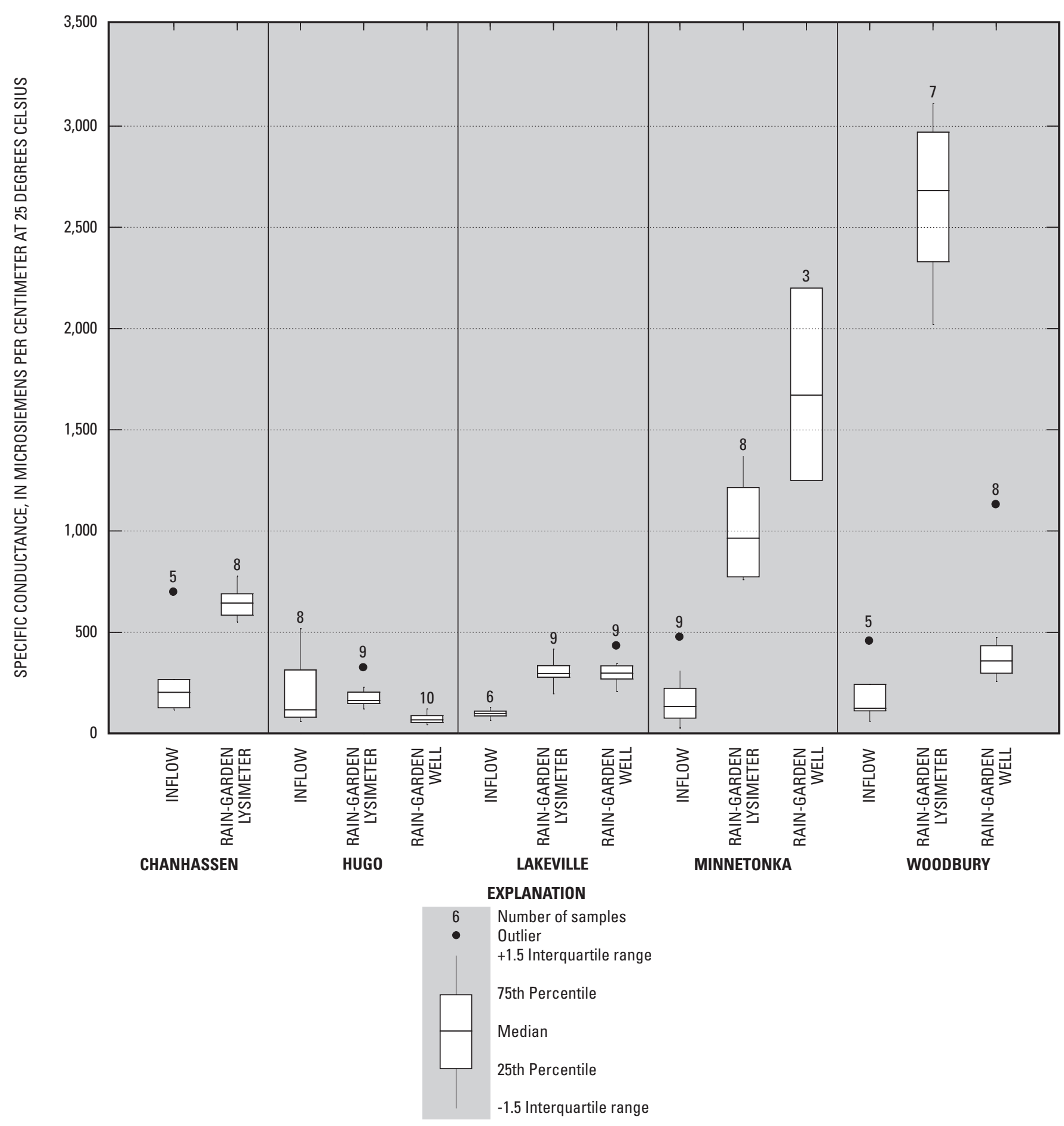

Figure 9. Distribution of specific conductance of water samples collected from inflow and rain-garden lysimeter and well at each of the five sites sampled in the Minneapolis-St. Paul metropolitan area of Minnesota, 2002-04. 

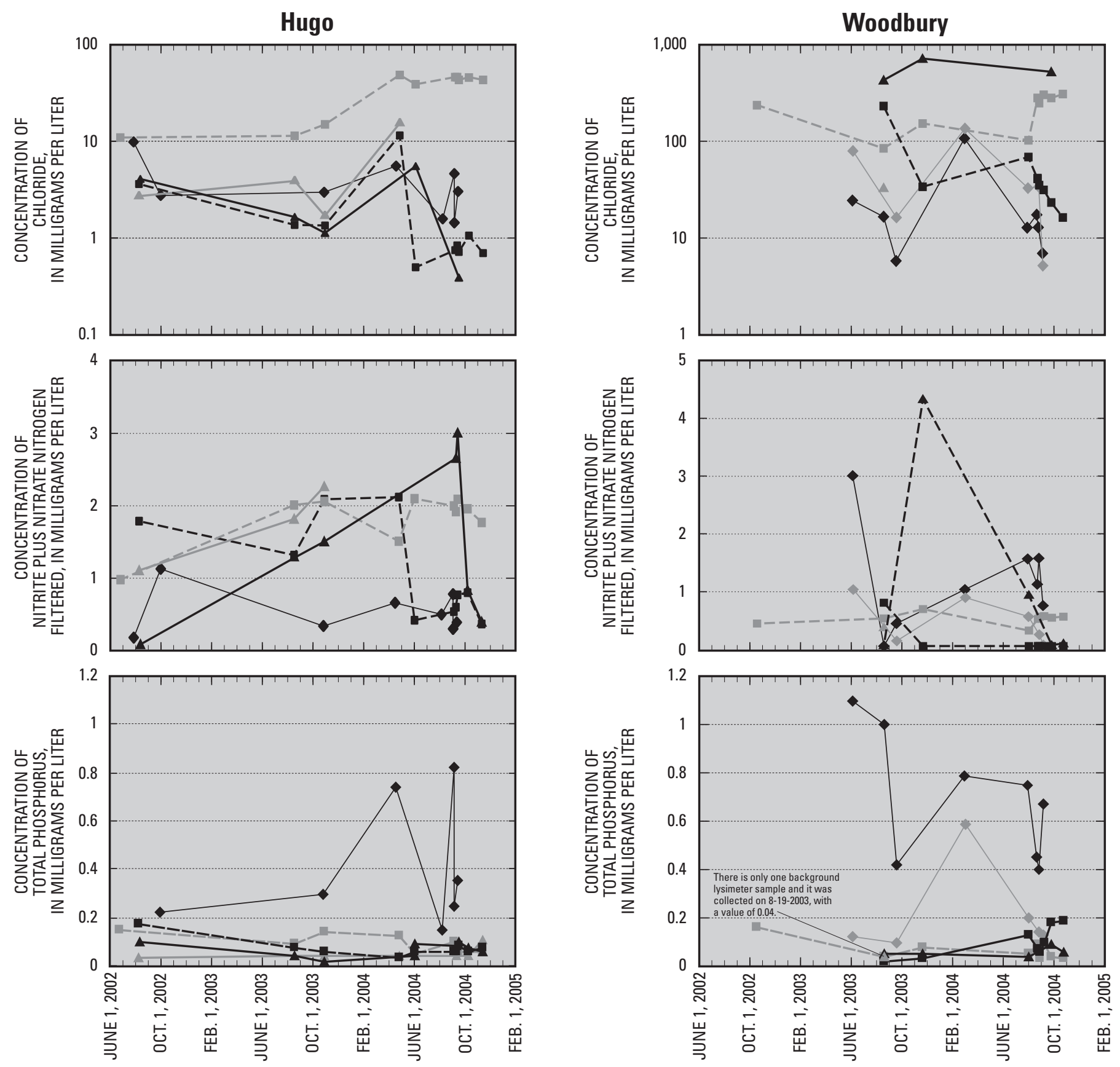

\section{EXPLANATION}

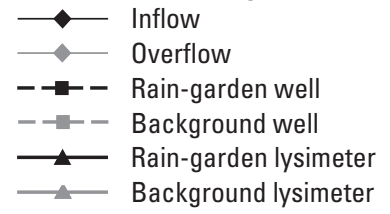

Figure 10. Change in chloride, nitrite plus nitrate nitrogen filtered, and total phosphorus concentration at the Hugo and Woodbury rain-garden sites in the Minneapolis-St. Paul metropolitan area of Minnesota, 2002-04. 
ity. Management officials have shown interest in learning more about the long-term aspects of these water-management systems.

Much of this study was conducted shortly after the rain gardens were constructed. Therefore, during the early part of this study many of the rain gardens had bare soil and little vegetation. More recently, the rain gardens have been planted with annual and perennial plants and flowers that may vary among sites. This temporal and spatial variability likely will affect the hydrologic characteristics within and among the rain gardens.

Precipitation during the early part of this study (2003) generally was less than normal (Mitton and others, 2004), resulting in few runoff events sampled. This also left soil conditions too dry to sample at many of the lysimeters, and water tables that declined below the screened intervals of some of the observation wells. In other cases, fresh vegetation plantings were augmented by irrigation that had an unpredictable effect on the water quality of recharge.

In all cases where both inflow and overflow were sampled, concentrations of suspended solids and associated materials including some plant nutrients were reduced in surface overflow. It is assumed that nutrient inflow would result in the benefit of enhanced plant growth within the rain gardens. This study did not address the effect of rain-garden maintenance on long-term water-quality effects. Although deposition of suspended solids could reduce infiltration, conduits caused by root systems may maintain pathways to convey water to the subsurface.

At some of the sites sampled there was evidence of changes in ground-water chemistry beneath the rain gardens. It is uncertain whether this is a temporary effect while the local ground-water system adjusts to the changes resulting from rain-garden installation or whether it is from other factors. There was active construction at the Chanhassen and Lakeville sites during much of this study. It likely will take time, possibly years because of the varying seasonal weather in Minnesota, for the systems to reach equilibrium with the variety of inputs including sediments, nutrients, and roadway runoff. We might learn that plants and wildlife not only enhance the aesthetic value of rain gardens, but help maintain their intended purpose of infiltration and reduction of overflow of nutrients and sediments into other surface-water bodies.

The data collected for this study provide a useful baseline that can be used to assess the long-term effects of rain gardens on water quality and associated ecosystems. Several unmeasured variables contribute some uncertainty to the results. Also, it is important to understand how these systems evolve over time and to be aware of what maintenance is required.

The interest in rain gardens as a management tool makes understanding the effects of these systems important to government and non-government organizations at many levels. It would be prudent to continue studying these sites to determine how they develop as a hydrologic system and understand how they behave during the long-term effects of weather variability. The weather encountered during this study was unusual, resulting in minimal runoff and conditions that resulted in reduced infiltration near background wells and lysimeters. Continued monitoring would provide more data from which to determine a better value for the range and central tendency of the results.

Several other factors also may add to the uncertainty of the results. Most of the sites are reasonably flat with various mixtures of grassland, undeveloped land, bare soils, and impervious surfaces. This makes determination of drainage areas and calculation of runoff difficult. Runoff arriving at a rain garden will vary depending on antecedent soil conditions (wet compared to dry, or frozen compared to thawed), wind direction affecting the movement of water across flat surfaces, and other factors that might affect the routing of flow into the rain garden. This study was equipped to sample only one primary inflow, even though several rain gardens have more than one source of inflow. The ability to measure the volume of inflow and overflow would help determine the ability of rain gardens to assimilate known quantities (loads) of materials introduced to them. Also, having only one background well and lysimeter required many assumptions about the site configuration that are useful, but may not be accurate. An additional assumption made was that the sampled inflow is representative of the quality of all inflow to the rain garden as compared to the overflow and ground-water recharge from the rain garden. Subsequent studies of these or other rain gardens could be designed to address, and hopefully quantify, many of these uncertainties.

\section{SUMMARY}

Rain gardens are being installed around the United States, including in several communities around the Minneapolis-St. Paul metropolitan area of Minnesota. Although data have been collected from some sites, few published studies document effects of the rain gardens on the quality of surface and ground water. To help address this need for information, a study was done by the USGS in cooperation with the Metropolitan Council of the Twin Cities, Department of Environmental Services, during 2002-04.

Rain gardens are a popular method of managing runoff while attempting to provide aesthetic and environmental benefits. Five rain-garden sites in the Minneapolis-Saint Paul metropolitan area were instrumented to evaluate the effects of this water-management system on surface and subsurface water quality. Most of these sites were in suburban locations and frequently in newer developments and therefore were affected by changing hydrology during the course of this study.

Less-than-normal precipitation during much of the study may have resulted in samples that may not be representative of normal conditions. However, the resulting data indicate that properly designed rain gardens enhance infiltration and can reduce concentrations of dissolved ions relative to background conditions. 
Sampling was focused primarily on determining the concentration of a few selected constituents considered to be indicative of runoff including suspended solids, nitrogen, phosphorus, chloride, and gross measures of dissolved constituents. Although the changes in mass transported throughout the system relative to sources were not measured, the data provide initial information to evaluate measured concentrations in components of the water system in a rain garden that was sampled and determine how they interrelate at each of the sites sampled. Other important factors including precipitation characteristics, antecedent conditions, and flow volumes from which to compute loads were not measured. Long-duration storms that exceeded the capacity of the automatic samplers were not adequately sampled. Other factors that could contribute to a better understanding of the systems including delineation of drainage areas, contributing drainage areas, and detailed information on land-use characteristics also were beyond the scope of this report. Determining how these samples relate to the existing climate or changing climate, changes in land use, and other factors also was beyond the scope of this report.

The runoff events in one rain garden and several runoff events in the other rain gardens produced no sampled overflow during this study because the gardens captured all of the inflow, which subsequently infiltrated beneath the land surface, evaporated, or transpired through garden vegetation. Where measured, overflow had reduced concentrations of suspended solids and most nutrient species associated with particulate material, as compared to inflow. Many of these materials settle to the bottom of the rain garden and some nutrients may be assimilated by the plant community.

Site design, including capacity relative to drainage area and soil permeability, is an important consideration in the efficiency of rain-garden operation. Vegetation type likely affects the infiltration capacity, nutrient uptake, and evapotranspiration of a rain garden and probably the resulting water quality. The long-term efficiency of rain gardens is difficult to determine from the results of this study because most are still evolving and maturing in relation to their hydrologic, biologic, and chemical setting. Many resource managers have questioned what long-term maintenance will be needed to keep rain gardens operating effectively. Additional or continued studies could address many of these concerns.

\section{SELECTED REFERENCES}

Fishman, M.J., and Friedman, L.C., eds., 1989: Methods for determination of inorganic substances in water and fluvial sediments: U.S. Geological Survey Techniques of WaterResources Investigation, book 5, chap. A1, 545 p.
Hanson, P.E., 1998, Pesticides and nitrate in surficial sand and gravel aquifers as related to modeled contamination susceptibility in part of the Upper Mississippi River Basin: U.S. Geological Survey Fact Sheet 107-98, 4 p.

Minnesota Department of Natural Resources, 2005a, Normal temperature maps, accessed August 10, 2005, at http://climate.umn.edu/doc/historical/temp_norm_adj.htm

Minnesota Department of Natural Resources, 2005b, Normal precipitation maps, accessed August 10, 2005, at http://climate.umn.edu/doc/historical/precip_norm.htm

Mitton, G.B., Guttormson, K.G., Stratton, G.W., and Wakeman, E.S., 2003, Water resources data in Minnesota, 2002: Annual Water-Data Report MN-02-1, variously paged.

Mitton, G.B., Guttormson, K.G., Stratton, G.W., and Wakeman, E.S., 2004, Water resources data in Minnesota, 2003: Annual Water-Data Report MN-03-1, variously paged.

Mitton, G.B., Guttormson, K.G., Stratton, G.W., and Wakeman, E.S., 2005, Water resources data in Minnesota, 2004: Annual Water-Data Report MN-04-1, variously paged.

Rain Garden Network, 2005, Local solutions for local stormwater issues, accessed August 24, 2005, at http://www. raingardennetwork.com/

U.S. Department of Agriculture, 2005, State soil geographic (STATSGO) data base for Minnesota, accessed April 19, 2005, at http://www.ncgc.nrcs.usda.gov/products/datasets/ statsgo/metadata/mn.html

U.S. Geological Survey, variously dated, National field manual for the collection of water-quality data: U.S. Geological Survey Techniques of Water-Resources Investigations, book 9, chaps. A1-A9, available online at http://pubs.water.usgs. gov/twri9A

Wood, W.W., 1976, Guidelines for collection and field analysis of ground-water samples for selected unstable constituents: U.S. Geological Survey Techniques of Water-Resources Investigation, book 1, chap. D2. 
